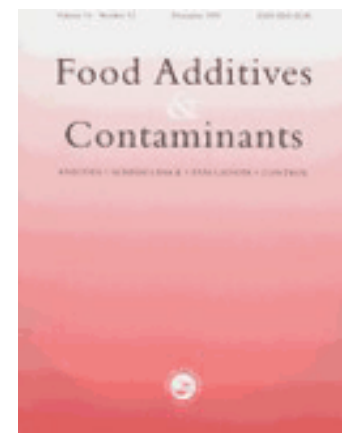

\title{
Review of mycotoxin reduction in food and feed: from prevention in fields to detoxification by adsorption or transformation
}

\begin{tabular}{|c|c|}
\hline Journal: & Food Additives and Contaminants \\
\hline Manuscript ID: & TFAC-2010-526.R1 \\
\hline Manuscript Type: & Review \\
\hline $\begin{array}{r}\text { Date Submitted by the } \\
\text { Author: }\end{array}$ & 24-May-2011 \\
\hline Complete List of Authors: & $\begin{array}{l}\text { Jard, Gwénaëlle; INRA, LBE } \\
\text { Liboz, Thierry; INP/ENSAT, Université de Toulouse } \\
\text { Mathieu, Florence; INP/ENSAT, Université de Toulouse } \\
\text { Guyonvarch, Alain; InVivo NSA } \\
\text { Lebrihi, Ahmed; INP/ENSAT, Université de Toulouse }\end{array}$ \\
\hline Methods/Techniques: & Toxicology, Microbiology, HPLC \\
\hline Additives/Contaminants: & Mycotoxins \\
\hline Food Types: & Animal feed, Cereals \\
\hline Abstract: & $\begin{array}{l}\text { Mycotoxins are secondary metabolites present worldwide in } \\
\text { agricultural commodities and produced by filamentous fungi that } \\
\text { cause a toxic response (mycotoxicosis) when ingested by animals. } \\
\text { Prevention of mycotoxicoses includes pre- and post-harvest } \\
\text { strategies. The best way to reduce the mycotoxin content in food } \\
\text { and feed is the prevention of mycotoxin formation in the field but } \\
\text { this is often not sufficient so that other methods are needed. To } \\
\text { decontaminate and/or detoxify mycotoxin-contaminated food and } \\
\text { feed, the most prevalent approach in the feed industry is the } \\
\text { inclusion of sorbent materials in the feed thus obtainig more or less } \\
\text { selective removal of toxins by adsorption during passage through } \\
\text { the gastrointestinal tract. Another reliable approach is to add } \\
\text { enzymes or microorganisms capable of detoxifying some } \\
\text { mycotoxins. Through a comprehensive review of published reports } \\
\text { on the strategies for mycotoxin removal, this present work aims to }\end{array}$ \\
\hline
\end{tabular}


update our understanding of mycotoxin removal. It could provide insight in the detoxification in mycotoxin present in food and feed. In the future, more emphasis should be placed on adsorption of mycotoxins in the gastrointestinal tract. Concerning the enzymatic transformation of mycotoxins, further effort is required in understanding detoxification reactions, the toxicity of transformation products and in the characterization of enzymes responsible for the transformations.

\section{SCHOLARONE}

Manuscripts 


\title{
Review of mycotoxin reduction in food and feed: from prevention in fields to detoxification by adsorption or transformation
}

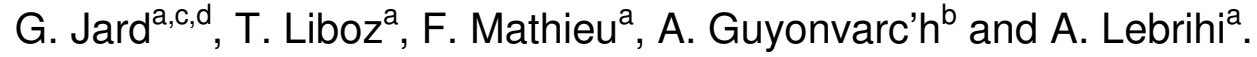

${ }^{a}$ INP/ENSAT, LGC, Université de Toulouse, Castanet-Tolosan, France ; ${ }^{\mathrm{b}}$ EVIALIS, Vannes, France ; 'INRA, UR050, Laboratoire de Biotechnologie de l'Environnement, Avenue des Etangs, Narbonne, France ; ${ }^{d}$ present address : El-Purpan, 75 voie du TOEC, Toulouse, France.

Corresponding author:

T. Liboz: liboz@ensat.fr

\begin{abstract}
Mycotoxins are secondary metabolites present worldwide in agricultural commodities and produced by filamentous fungi that cause a toxic response (mycotoxicosis) when ingested by animals. Prevention of mycotoxicoses includes pre- and post-harvest strategies. The best way to reduce the mycotoxin content in food and feed is the prevention of mycotoxin formation in the field but this is often not sufficient so that other methods are needed. To decontaminate and/or detoxify mycotoxin-contaminated food and feed, the most prevalent approach in the feed industry is the inclusion of sorbent materials in the feed thus obtaining more or less selective removal of toxins by adsorption during passage through the gastrointestinal tract. Another reliable approach is to add enzymes or microorganisms capable of detoxifying some mycotoxins. Through a comprehensive review of published reports on the strategies for mycotoxin removal, this present work aims to update our understanding of mycotoxin removal. It could provide insight in the detoxification in mycotoxin present in food and feed. In the future, more emphasis should be placed on adsorption of mycotoxins in the gastrointestinal tract. Concerning the enzymatic transformation of mycotoxins, further effort is required in understanding detoxification reactions, the toxicity of transformation products and in the characterization of enzymes responsible for the transformations.
\end{abstract}

KEYWORDS: mycotoxins; decontamination; adsorption; binding agents; sequestering agents; transformation; detoxification.

\section{Introduction}

Mycotoxins are secondary metabolites produced by filamentous fungi that cause a toxic response (mycotoxicosis) when ingested by animals. Plants can be contaminated in two 
ways: fungi growing either as pathogens on plants in field or on stored plants (Glenn, 2007). All moulds are not toxigenic and while some mycotoxins are produced by only a limited number of species, others may be produced by a relatively large range from several genera. Up to now, there have been reported approximately 400 secondary metabolites with toxigenic potential produced by more than 100 moulds. Examples of some well-known mycotoxins are aflatoxins, fumonisins, ochratoxin, trichothecenes, zearalenone, penitrems and ergot alkaloids. The Food and Agriculture Organization (FAO) estimates that $25 \%$ of the world's agricultural commodities are contaminated with mycotoxins, leading to significant economic losses (Wu, 2007). Mycotoxins are small and quite stable molecules which are extremely difficult to remove or eradicate, and which enter the feed chain while keeping their toxic properties. Consumption of a mycotoxin-contaminated diet may induce acute and longterm chronic effects in animals and humans resulting in teratogenic, carcinogenic and oestrogenic or immune-suppressive effects. Data on mycotoxin levels in mycotoxin contamination causing a reduction in zootechnical performance in farm animals (ruminants, pigs and poultry) were compiled in the AFSSA report (Afssa, 2009). Direct consequences of consumption of mycotoxin-contaminated animal feed include: reduced feed intake, poor feed conversion, diminished body weight gain, increased incidence of disease (due to immunesuppression) and reduced reproductive capacity (Fink-Gremmels and Malekinejad, 2007; Morgavi and Riley, 2007; Pestka, 2007; Voss et al., 2007).

The diversity of mycotoxin structures induces diverse toxic effects. For example, the aflatoxin structure permit the formation of DNA adducts with guanine inducing cancerous cell formation (Bren et al., 2007). The lactone ring of aflatoxins is responsible for its toxicity (Lee et al., 1981). Fumonisins could inhibit the ceramide synthase (Soriano et al., 2005) inducing adverse effect on the sphinganin/sphingosin ratio. The deamination of fumonisin B1 induces a loss of toxicity indicating that amine play a role in fumonisin toxicity. Ochratoxins affect the protein synthesis and inhibit the ATP production. The toxicity of ochratoxins is associated with its isocoumarin moiety (Xiao et al., 1996). Deoxynivalenol (DON) and T-2 toxin induce apoptosis in haemopoietic progenitor cells and immune cells (Parent-Massin, 2004). They also inhibit protein, ADN and ARN synthesis (Richard, 2007). The epoxy structure of trichotecenes induces their toxicity (Sundstøl Eriksen et al., 2004). Zearalenone (ZEA) thanks to its conformation is able to mimick $17 \beta$-estradiol and to bind to estrogen receptors disrupting fertility and reproduction ability (Gaumy et al., 2001).

Prevention of mycotoxicoses includes pre- and post-harvest strategies. The best way is the prevention of mycotoxin formation in the field but this is often not sufficient and other strategies are needed. To decontaminate and/or detoxify mycotoxin-contaminated food and feed, the most prevalent approach in the feed industry is the inclusion of sorbent materials in the feed to obtain more or less selective removal of toxins by adsorption during passage through the gastrointestinal tract, or to add enzymes or microorganisms capable of detoxifying certain mycotoxins. A new functional group of feed additives as "substances for 
reduction of the contamination of feed by mycotoxins: substances that can suppress or reduce the absorption, promote the excretion of mycotoxins or modify their mode of action" was defined by the Commission regulation (EC) No 386/2009 of 12 May 2009. Depending on their mode of action, these feed additives may act by reducing the bioavailability of the mycotoxins or by degrading them or transforming them into less toxic metabolites.

Through a comprehensive review of published reports on the strategies for removing mycotoxins by both adsorption and transformation, this present work aims to update our understanding of removal of mycotoxins and it could provide insight in the elimination and detoxification in mycotoxin present in food and feed. Numerous recent reports have been previously published on part of this field (Kabak et al., 2006; Schatzmayr et al., 2006; Jouany, 2007; EFSA, 2009; Awad et al., 2010; He et al., 2010) but none of them propose an overview on mycotoxin elimination from prevention in fields to mycotoxin detoxification.

\section{Preventive strategies: controlling mould development}

Moulds can develop on plants or plant products during cultivation or storage. Depending on environmental conditions, some of these moulds may produce mycotoxins leading to harmful consequences for consumers. So, primary strategy should aim to eliminate mycotoxins reducing mould proliferation during cultivation and storage. Magan and Aldred (2007) synthesized interesting studies on this topic. In the following discussion, we will mention a number of strategies which could be used.

\section{Planting}

Crop varieties selection

Seeds must be free of pests and disease before planting, to ensure healthy, vigorous plants capable of withstanding attack during the growing season. A possible strategy is also to select crop varieties on their ability to resist mould attack (Clements and White, 2004).

Sowing date

Sowing date is another element of crop management that has an indirect effect on the production and infection by spores because it partly determines the flowering date, together with the variety sown and prevailing weather. If the sowing date is such that flowering coincides with spore release, then more frequent and severer attacks are likely (Champeil et al., 2004). As far as practical, crop planting should be timed to avoid high temperature and drought stress during the period of seed development and maturation (Codex alimentarius, 2003).

\section{Pre-harvest}

Suitable cultivation techniques 
In the first place, using suitable cultivation techniques can reduce the risk of fungal contamination. For example, removal of agricultural waste is effective in preventing the contamination of the follow-on crops. Indeed, the primary reservoir of fungal inoculum is the residues from previous crops. Also, ploughing limits mould contamination (Munkvold, 2003; Champeil et al., 2004). The effects of crop rotation are also significant. For example, wheat following maize in the rotation has been found to have DON concentrations six times higher than those in wheat following another cereal (wheat, barley) or soybean (Krebs et al., 2000). In that context, Codex alimentarius (2003) established some good agricultural practices for farmers for the prevention and reduction of mycotoxin contamination in cereals. For example, it is suggested to use crops such as potato, other vegetables, clover and alfalfa that are not hosts to Fusarium species in rotation to reduce the inoculum in the field. Drought stress, caused by a lack of water, is known to facilitate attack by mould. Lack of water allows the plant to crack, and so opens passage ways through which fungal spores can enter.

\section{Predictive models}

Softwares applications are available to help farmers predict mycotoxin risk during the year as a function of climatic parameters (Schaafsma and Hooker, 2007; Prandini et al., 2009). Fungicides could be useful whenever a predictable risk exists (Paul et al., 2008). However, risk management must take into account other risks for consumer health linked to the presence of fungicides in food. In this context, a recent study compared the toxicity of two fungicides and two mycotoxins, ZEA and DON (Muri et al., 2009). The final results showed that DON was more toxic than both ZEA and the two tested fungicides. However, other studies have shown that conventional agriculture using fungicides induces higher risks than organic farming (Finamore et al., 2004; Schneweis et al., 2005). For example, maize from an organic farm had a $50 \%$ lower Fusarium infection rate than maize from a conventional farm probably due in large part to the lower intensity of cultivation, different crop rotation, ploughing and the heightened biomass activity of organic soils (Arino et al., 2007).

Avoiding insect attack

It is known that incidence of infection from $A$. flavus and $A$. parasiticus in damaged kernels is significantly high in comparison with healthy ones. Insects can act as fungal spore vectors or to create critical points in the commodity mass favouring fungal growth and toxin production (Sinha and Sinha, 1990). Furthermore, they attack kernel external teguments and facilitate entry and colonization of mycotoxin-producing fungi. Therefore, treatments with insecticides are advisable to reduce these attacks.

Biocontrol techniques

In the fight against fusariotoxicosis, biocontrol techniques based on microorganisms are also

under study to fight against (Schisler et al., 2002). Different microorganisms have been 
proposed as bio-control agents of $A$. flavus and aflatoxins contamination in pre-harvest; nonaflatoxigenic isolated strains of the same species could be optimal bio-competitive agents. For example, Dorner and Cole (2002) showed that treatment of soil with nontoxigenic strains of $A$. flavus and $A$. parasiticus significantly reduces preharvest aflatoxin contamination. In addition, soil treatment with nontoxigenic strains had the beneficial carry-over effect of reducing aflatoxin contamination that occurred during storage.

\section{Post-harvest}

\section{Storage}

This step is critical in preventing mold growth and mycotoxin production in harvested feedstuffs. Various important factors should be managed to prevent crops from fungal contamination during storage (Schrödter, 2004). For example, grain should be stored with less than $15 \%$ moisture content to eliminate pockets with higher moisture (Kabak et al., 2006) at low temperature (Burges and Burrel, 1964). A low oxygen concentration (<1\%) and an augmentation of carbon dioxide concentration are efficient to prevent mould development (Driehuis and Oude-Elferink, 2000). Physical integrity of grains should be preserved. Mixing grains and a long-time storage should be avoided.

Despite all precautions, it may happen that stored grain will become damaged by mould. It must then be assumed that the grain could also be contaminated with mycotoxins. If the farmer has plenty of grain in store, he can afford to lose a small quantity that has turned mouldy. Ideally, the farmer must discard mouldy grain and any that is suspected of being contaminated with mycotoxins; this will include apparently clean grain that is in the vicinity of the mouldy produce. This grain should be burnt or buried.

\section{Sorting}

Contaminated grain does not have the same color or density as safe grain. Thus, grain can be sorted according to appearance or density (Murphy et al., 1993; Guerre, 2000; Afolabi et al., 2006; Kabak et al., 2006). These methods are not very specific and in general not exhaustive. When mycotoxin contamination is heterogeneous. the removal of the contaminated part could reduce the level of mycotoxin in the fincu Humidité (\%) 1978; Osborne et al., 1996). For example, apple dissection before making apple juice led to a $95 \%$ reduction of patulin (Lovett et al., 1975). Washing of food or grain can also reduce mycotoxin levels. For example, the first step in spaghetti production with wheat is a washing which remove of $23 \%$ of DON (Visconti et al., 2004). 


\section{Eliminating mycotoxins from food and feed}

Different methods must be used to decontaminate food and feed before ingestion. For the moment, regulations do not permit the decontamination of food that exceeds the limit concentration thresholds. Mycotoxin reduction could be carried out during food industry processes (Bullerman and Bianchini, 2007) or by using additives which eliminate or deactivate mycotoxins in the organism. In all cases, decontamination processes should destroy or inactivate mycotoxins, generate no toxic products, guaranty the nutritional value of the food and induce no modification to the technological properties of the product.

\section{Decreasing bioavailibility of mycotoxins by adsorption}

\section{Principle}

Since all mycotoxins are very stable substances, no physical or chemical treatment can be applied without altering the nutritional value of the grain or causing a high rise in costs. For example, ammonia or strong oxidizing agents can reduce the contamination but will also reduce at the same time the nutritional value of the feed.

The most commonly-used technique for reducing exposure to mycotoxins is to decrease their bio-availability by the inclusion of various mycotoxin binding agents or adsorbents, which leads to a diminishing of mycotoxin uptake and subsequent distribution to the blood and target organs. These adsorbants are efficient only if the complex is stable in an animal digestive tract so that bound mycotoxins are channelled to its urine and feces.

An important criterion for the evaluation of mycotoxin adsorbants is their effectiveness at different levels of $\mathrm{pH}$ (acidic and neutral) since the adsorbant must be efficient throughout the entire gastro-intestinal tract and that the complex mycotoxin-adsorbant remains stable, in order to prevent desorption of the toxin during the digestion.

The properties of both adsorbant and mycotoxin play an important role in adsorbant efficacy. Indeed, the physical structure of an adsorbant, including such features as total charge and distribution, pore size and surface accessibility, must be studied. The characteristics of mycotoxins such as polarity, solubility, molecular size, shape and, in the case of ionised compounds, charge distribution and dissociation constants, are also very important.

Binders have been evaluated using both in vitro and in vivo systems. In vivo studies have generally used performance responses or biological markers such as tissue residues or changes in biochemical parameters to determine the effectiveness of binders. Numerous binders are efficient to bind aflatoxin but few of them could be used for other mycotoxins (EFSA, 2009). 


\section{Mineral and organic adsorbants}

Activated charcoal. Activated charcoal is formed by the pyrolysis of organic materials. It is a general adsorptive material with a large surface area and excellent adsorptive capacity. Thanks to its porosity, activated charcoal can adsorb the main mycotoxins in an aqueous environment. In one of the first studies to test the concept of mycotoxin binding, activated charcoal was shown to efficiently adsorb AFB1 (Decker and Corby, 1980). In subsequent studies, the effects of activated charcoal have been variable. Galvano et al. (1996) showed reduced aflatoxin residues in milk of cows consuming different sources of charcoal, but responses to charcoal did not exceed that seen with a clay-based binder, a hydrated sodium calcium aluminosilicate or HSCAS (Diaz et al., 2004). Responses to charcoal suggest that charcoal may not be as effective in binding aflatoxin as clay-based binders (Edrington et al., 1996, 1997). Activated charcoal may be interesting in binding ZEA and/or DON (Döll et al., 2004; Bueno et al., 2005; Sabater-Vilar et al., 2007). In an in vitro gastrointestinal model, activated carbon reduced availability of ZEA, DON and nivalenol (Avantaggiatto et al., 2003, 2004). However, adsorption of ochratoxin A (OTA) does not lead to a positive effect on chicken body weight (Rotter et al., 1989). On FB1, the ratio sphinganine/shingosine was not modified in rats after charcoal was added to contaminated feed (Solfrizzo et al., 2001). For T2 and HT-2 toxins, responses have been variable depending on the animals. For example, a $50 \%$ survival rate for mice fed with contaminated feed was observed while a $90 \%$ survival rate was reached after the addition of charcoal (Fricke and Jorge, 1990). On the other hand, there was no effect on chicken: a decrease in $20 \%$ of body weight was observed with or without treatment.

Silicate binders. Silicates are divided into subclasses according to their structure. One such group is the phyllosilicate family, characterised by a sheet-type framework. Perhaps the most extensively studied of these materials is termed hydrated sodium calcium aluminosilicates (HSCASs). Several reviews are available (Ramos et al., 1996; Döll and Dänicke, 2004; Avantaggiato et al., 2005). $80 \%$ of AFB1 could be adsorbed by HSCASs in vitro (Phillips et al. 1988) and could prevent aflatoxicosis. Positive effects of other HSCASs on drosophile progeny (Sisman, 2006) were also observed. Furthermore, responses to HSCASs appear to be dose dependent (Smith et al., 1994). HSCASs are thought to absorb aflatoxin selectively during the digestive process, which renders much of the aflatoxin unavailable for absorption from the gastrointestinal tract (Kubena et al., 1990). The chemisorption of aflatoxin to HSCAS involves the formation of a complex by the $\beta$-keto-lactone or bilactone system of aflatoxin with uncoordinated metal ions in HSCAS (Sarr et al., 1990). AFB1 may react at surfaces and within the interlayers of HSCAS particles (Phillips et al., 1995, 2002, 2008). Some sorbents such as NovaSil clay act as selective enterosorbents since they do not affect the serum concentrations of important vitamins and nutrient minerals in humans (AfriyieGyawu et al., 2008). 
In general, HSCAS have low affinity with OTA (Huff et al., 1992; Galvano et al., 1998). Adsorption results for ZEA are variable: some studies show a decrease in chromosomic aberrations for mice (Abbes et al., 2007) and a positive effect on the length of mink gestation (Bursian et al., 1992). Patterson and Young (1993), however, failed to see any benefit in the addition of HSCAS to pig diets containing DON. This result was confirmed in vitro by Galvano et al. (1998) and Sabater-Vilar et al. (2007). Garcia et al. (2003), using a silicate material, demonstrated reduced T-2 toxicity while Kubena et al. (1990) did not see any effect from the addition of HSCAS. Aly et al. (2004) showed an adsorption efficiency fir a mix of AFB1 and FB1 of, respectively, 95\% and 85\%. However, Watts et al. (2003) showed that $1 \%$ HSCAS did not protect chicks and poults receiving diets containing $1 \mathrm{mg}$ DON, $5 \mathrm{mg}$ moniliformin, $5 \mathrm{mg}$ FB1, $100 \mu \mathrm{g}$ AFB1, $1 \mathrm{mg}$ ZEA and $0.5 \mathrm{mg}$ OTA per $\mathrm{kg}$ of diet.

Other silicates that have been studied include bentonites, zeolites, clinoptilolites and various others that often have not been completely characterized. Bentonite is a general clay material originating from volcanic ash and containing primarily montmorillonite as the main constituent. Montmorillonite clay is a hydrated sodium calcium aluminum magnesium silicate hydroxide. Clays are silica sheets that are similar to other phyllosilicates but contain a high concentration of water. The zeolite structure provides vacant spaces that form channels of various sizes allowing movement of molecules into and out of the structure. Thanks to this structure, zeolithes present a very big specific surface (about $1000 \mathrm{~m}^{2}$ per gramme of zeolithe).

Bentonite and montmorillonite could adsorb from $40 \%$ to $100 \%$ of OTA in wine (Kurtbay et al., 2008). However, Lemke et al. (2001a) failed to show a positive in vivo effect on rats. Indeed, rat uterus weight increased with montmorillonite treatments suggesting an increase of oestrogenic toxicity with treatment. A slight positive effect was observed by Carson and Smith (1983a) for the addition of bentonite in T-2 toxin-contaminated food since $8 \%$ of body weight was recovered after treatment. A $9 \%$ body weight gain was observed for chicken treated with bentonite when their feed contained a mix of AFB1 and FB1 (Miazzo et al., 2005). Another study performed by Kubena et al. (1998) demonstrated that an HSCAS could provide protection against AFB1 but not against T-2 toxin in young broiler chicks.

Zeolites are very efficient in bovine rumen juice since $100 \%$ of AFB1 was adsorbed (Spotti et al., 2005). Zeolites have not proven to reduce the toxicity of T-2 toxin (Dvorska and Surai, 2001). However, some types of clinoptilotite could not be used as a binder since its adding in presence of AFB1 caused severe lesions. This could be explained by a nonspecific adsorption of important compounds involved in aflatoxicosis regulation (Mayura et al., 1998).

A number of studies have examined chemically-modified silicates. Döll et al. (2004) examined a chemically-modified aluminosilicate that showed good binding with ZEA in vitro, confirming previous work (Lemke et al., 1998; Tomasevic-Canovic et al., 2003). Others have 
shown that chemical modifications have increased the binding of HSCAS with ZEA (Pimpukdee et al., 2004). Non-modified zeolithes are used to adsorb AFB1 while hydrophobic zeolithes (octadecyldimethylbenzyl, an ammonium-treated zeolite) are mostly used to adsorb OTA and ZEA (Dakovic et al., 2003, 2005, 2007). The adsorption efficiency of hydrophobic zeolithes could be explained by hydrophobic interactions between OTA and ZEA and the binder.

Other mineral adsorbants. Some synthetic polymers such as cholestryamine and polyvinylpyrrolidone can adsorb mycotoxins. Undigestible dietary fiber has adsorbance potential for mycotoxins. Fibers have reduced the effects of ZEA (Tangni et al., 2006) in rats and swine and T-2 toxin in rats (Carson and Smith, 1983b). Cholestyramine resin is used in human medicine for the reduction of cholesterol and functions through adsorption of bile acids. Cholestyramine has been shown to adsorb ZEA (Ramos et al., 1996; Döll et al., 2004; Avantaggiato et al., 2005) and FB1 (Solfrizzo et al., 2001). In rats consuming OTA, cholestyramine increased fecal OTA excretion (Kerkadi et al., 1998). In another in vivo study, cholestyramine did not bind OTA (Bauer, 1994). Only 5\% of DON could be adsorbed by cholestyramine in a dynamic digestive tract (Avantaggiato et al., 2005).

A synthetic water-soluble polymer, polyvinlypyrrolidone (PVP), has been investigated as a binder for mycotoxins. PVP is reported to bind with AFB1 and ZEA in vitro (Alegakis et al., 1999) but did not alleviate the toxicity of DON seen in pigs (Friend et al., 1984).

Some commercial adsorbants consist of a mixture of different adsorbants. For example, the product Standard Q/FIS allies charcoal and HSCAS. These products are in general tested for their capacity to adsorb various mycotoxins at the same time (Avantaggiato et al., 2007).

Limits of mineral adsorbants. Mineral adsorbants are in general efficacious against AFB1 but their efficacy varies for other mycotoxins. Moreover, in some cases, the addition of clay increases the effects of mycotoxicosis (Carson and Smith, 1983a; Mayura et al., 1998; Lemke et al., 2001a). Furthermore, these adsorbants are not specific to mycotoxins and could adsorb other types of molecules, some of which essential for fighting mycotoxicosis or in nutrition (Mayura et al., 1998).

Organic adsorbants. Humic acids are complex organic substances, a component of humus. They also have the capacity to adsorb mycotoxins, especially AFB1 and ZEA (Jansen van Rensburg et al., 2006) but not DON (Sabater-Vilar et al., 2007).

\section{Biological adsorbants}

Because of the limitations of mineral adsorption, many studies have been conducted over the last decade on biological adsorbents, trying to obtain greater efficacy and specificity 
and at the same time reducing the impact on nutritional quality compared to mineral adsorbents.

Yeast or yeast extract. One example is Saccharomyces cerevisiae which has been shown to bind with AFB1 (Shetty and Jespersen, 2006) and reduce the detrimental effects of AFB1 in broiler diets (Stanley et al., 1993) or on rats (Madrigal-Santillán et al., 2006). The protective effect of live yeast against aflatoxin was confirmed in rats but thermolysed yeast was shown to be ineffective (Babtista et al., 2002). In contrast, some thermolysed yeast cell walls were more efficient in adsorbing ZEA (Yiannikouris, 2004). Esterified glucomannan polymer extracted from the yeast cell wall was shown to bind with AFB1, OTA (Bejaoui et al., 2004; Cecchini et al., 2007; Angioni et al., 2007) and T-2 toxin (Freimund et al., 2003), individually and in combination (Raju and Devegowda, 2000; Yiannikouris, 2004; Aravind et al., 2003; Karaman et al., 2005). Additions of esterified glucomannan at 0.5 or $1.0 \mathrm{~g} / \mathrm{kg}$ to diets containig $2 \mathrm{mg}$ of total aflatoxin resulted in dose-dependent responses in broiler chicks (Basmacioglu et al., 2005). The addition of esterified glucan polymer to aflatoxincontaminated diets of dairy cows has significantly reduced milk aflatoxin residues (Diaz et al., 2004). The body weight and biochemical parameters were recovered in horses after adding glucomannan to their diet (Raymond et al., 2003).

Yiannikouris et al. (2004) demonstrated the mechanism of binding yeast-modified glucan with ZEA. A glucan polymer bound both T-2 toxin and ZEA in vitro (Freimund et al., 2003). The glucan polymer product gave protective against depression in antioxidant activities resulting from T-2 toxin consumed by growing quail (Dvorska and Surai, 2001). A glucan polymer product has protected swine, broilers (Swamy et al., 2002a, b) and hens (Chowdhury and Smith, 2004) against some of the detrimental effects of multiple mycotoxins, but without restoring growth rate. Aravind et al. (2003), using dietary additions of $0.5 \%$ esterified glucomannan, alleviated growth depression in broilers associated with naturallycontaminated diets containing AFB1, OTA, ZEA and T-2 toxin. A glucan polymer product did not alleviate the toxic effects on mink consuming diets contaminated with FB1, OTA, moniliformin and ZEA (Bursian et al., 2004). The negative effects of ZEA and DON as measured by biochemical and immunological parameters in pig were alleviated by adding yeast extract enriched in glucomannan to their diet (Swamy et al., 2002a). $183 \mathrm{mg}$ of T-2/HT2 toxin was adsorbed per gramme of yeast-modified glucan in vitro (Freimund et al., 2003). FB1 adsorption by yeast or yeast extract is limited (Yiannikouris, 2004). T-2 and HT-2 binding responses are variables on yeast-modified glucan (Freimund et al., 2003).

Lactic acid bacteria. The parietal structures of some lactic acid bacteria, propionibacteria and bifidobacteria have the capacity to bind mycotoxins (El-Nezami et al., 2000, 2002a; Haskard et al., 2001; Oatley et al., 2000). The binding appears to be physical with DON, diacetoxyscerpenol, nivalenol, and other mycotoxins associated with hydrophobic pockets on 
the bacterial surface (Haskard et al., 2000; El-Nezami et al., 2004). Adsorption efficiency depends on strains (Peltonen et al., 2001). Adsorption of AFB1 and AFM1 was reversible and could be performed with living or dead bacteria. Acid or heat inactivation of lactic acid bacteria increased adsorption efficiency (Haskard et al., 2001; Pierides et al., 2000; ElNezami et al., 1998, 2000, 2002b; Bueno et al., 2007; Fazeli et al., 2009). OTA could also be adsorbed by lactic acid bacteria (Fuchs et al., 2002) and led to a diminution of toxicity on human hepatic cells (Del Prete et al., 2007). ZEA could be adsorbed between pH 4 and pH 8 (El-Nezami et al., 2002b) and heat or acid inactivation increased adsorption efficiency (Niderkorn et al., 2006; El-Nezami et al., 1998, 2002b). Binding on FB1 and DON by L.rhamnosus was not a very efficient solution (Niderkorn et al., 2006). Hydrophobic interactions were suspected to be involved in the binding (Haskard et al., 2001).

Other biological materials. Fungal conidia are able to bind mycotoxins and especially ZEA and OTA, separatly or together (Jard et al., 2009). From $29 \%$ to $60 \%$ of ZEA were eliminated depending on the isolate and incubation time. Jard et al. (2009) suggested a hydrophobic interaction based on conidia wall characteristics. It has been suggested that conidia could be used to decontaminate wine affected by OTA (Bejaoui et al., 2005).

\section{Binder efficiency}

Many solutions are available for binding mycotoxins but few of them are actually used in an industrial context. Decreasing the bioavailability of AFB1 by the inclusion of binding agents is particularly effective as this group of toxins has a chemical structure which favors adsorption, especially by materials of mineral origin such as clay and zeolites. OTA, ZEA and FB1 adsorption has been more extensively studied with biological adsorbents on account of the lack of efficacy of mineral adsorbents. DON and T-2 or HT-2 toxin do not bind easily on every kind of binding agents.

A binder must be effective at sequestering the particular mycotoxin(s) targetted. In some cases, it may be of interest to bind one specific mycotoxin whereas in others, binding multiple mycotoxins may be the objective. A binder should significantly prevent toxicity in animals. There should be no serious side effects on an animal or at least, detrimental effects should not outweigh the benefits. Costs should render its use practical and profitable. Mycotoxins residues from animals or products should not increase. Nor should there be any detrimental effects on the animal food product. Mycotoxins in feed should not be masked such that feed contamination cannot be verified. The binder should be physically usable in a commercial feed manufacturing context. Binder use and efficacy should be verifiable. Interaction between an adsorbent and mycotoxins must produce a very strong bond in order that washing or interaction with nutrients in the digestive tract does not desorb bound mycotoxins. Adsorption must be as specific as possible so that essential molecules will not also be bound. Most of adsorbing agents, especially aluminosilicates, have been tested for 
their ability to bind aflatoxins. The mycotoxins targeted by yeast cell wall, bacteria and other adsorbing agents are more diverse.

\section{Detoxification of mycotoxins by transformation}

\section{Transformation by physical and chemical treatment}

Few physical or chemical processes can transform mycotoxins into non-toxic products. Those most studied are presented below. In Kabak et al. (2006), an interesting detailed review is available dealing with this topic. He et al. (2010) reviewed the chemical and biological transformations for detoxification of trichothecene mycotoxins.

Thermal treatment. Mycotoxins are generally very stable and can hardly be eliminated by thermic treatment (Kabak, 2009). Little or no reduction in mycotoxin levels occurs as a result of normal cooking conditions such as boiling, frying. For example, DON is stable at $120^{\circ} \mathrm{C}$, moderately stable at $180^{\circ} \mathrm{C}$ and partially stable at $210^{\circ} \mathrm{C}$ (WHO, 2001). Fumonisins are completly destroyed at $220^{\circ} \mathrm{C}$ (Dupuy et al., 1993). Torrefaction process could eliminate between 45 and $83 \%$ of aflatoxin content while panification or pasteurization is not efficient to remove aflatoxin (CAST, 2003). Thermal treatment on ZEA contaminated food is not efficient (Ryu et al., 2003). The initial level of contamination, type of mycotoxin and its concentration, heating temperature and time, the degree of heat penetration, the moisture content, $\mathrm{pH}$, ionic strength of food play a significant role in the achievement of toxin degredation (Rustom, 1997).

Degradation by extrusion. Extrusion enables aflatoxins, DON, ZEA and FB1 to be removed from maize (Cazzaniga et al., 2001; Rustom, 1997; Voss et al., 2008). Extrusion implies molecular modifications such as protein denaturation and the inhibition of the enzymatic activity.

Radiation. Most mycotoxins have complex molecular structures and are not often affected by irradiation. Radiolysis of water produces free radicals that would react with mycotoxins (Stepanik et al., 2007). AFB1 is sensitive to UV, $X$ and gamma rays. Radiation of AFB1 is able to reduce its level of contamination (Rustom, 1997; Afifi et al., 2003). Gamma radiation can also reduce microbial flora. Using micro-waves permit the reduction of aflatoxin content inpeanuts (Farag et al., 1996) and trichotecenes in corn (Scott, 1998).

Oxydation. Some oxidizing agents like ozone and hydrogen peroxyde have been used to render mycotoxin-contaminated feed harmless. Chemical oxidizing agents can react with numerous functional groups. McKenzie et al. (1998) showed that a treatment of contaminated corn with electrochemically produced $\mathrm{O}_{3}$ provided protection against AFB1 in young turkey poults. Canadas (2006) studied the efficacy of the Oxygreen $\AA$ process using ozone on OTA-contaminated cereals. The Oxygreen ${ }^{\circledR}$ process permitted the reduction of microbiological and mycotoxin contamination but it seems to induce some side effects such as ADN adducts in wheat. Abd Alla (1997) revealed that ZEA was degraded by $83.9 \%$ when 
using $10 \% \mathrm{H}_{2} \mathrm{O}_{2}$ at $80^{\circ} \mathrm{C}$ for $16 \mathrm{~h}$. It was confirmed by Lemke et al. (1999) showing ozone could prevent the estrogenic effects of ZEA in mice. Biological activities of trichothecenes are also changed by oxidation. Ozone is most likely to attack the double bond in trichothecenes (McKenzie et al., 1997).

Reduction. Reducing agents (ascorbic acid, $\mathrm{NaHSO}_{3}, \mathrm{Na}_{2} \mathrm{~S}_{2} \mathrm{O}_{5}$ ) permitting the reduction of such mycotoxins as AFB1 and DON (Kabak et al., 2006). Sodium bisulfite transforming DON to DON-sulfonate, which is less toxic than DON, was reported to be an effective tool for overcoming the depressive effects of Don on feed-intake in piglets (Dänicke et al., 2005).

The reaction of FB1 with reducing sugars such as D-glucose, D-fructose at $65^{\circ} \mathrm{C}$ for $48 \mathrm{~h}$ can block the primary amino group of FB1, and seems to prevent FB1-induced toxicity on cell tissue cultures on rats and swine (Fernandez-Surumay et al., 2005).

Ammoniation. Maize ammoniation, largely used to diminish the level of aflatoxins in feed is an efficient method for detoxifying feed that has been in use for several years (Park et al., 1988). This process is particularly effictive against AFB1 when carried out at high temperature and pressure. One of the degradation products is AFD1, less toxic than AFB1. However, this costly method is not effective against other mycotoxins and can damage food quality because of an excessive level of ammonia in the food involved (Huwig et al., 2001).

Alkalization. Under alkaline conditions, mycotoxins structure can change. For example, under alkaline conditions, the 12-13 epoxy group of DON could be opened (Bretz et al., 2006). Acidification. Treatment of aflatoxins with strong acids destroys the biological activity of AFB1 converting them to the hemi-acetal form (Heathcote and Hibbert, 1978). Treatment with $\mathrm{HCl}$ (pH 2) has been shown to reduce AFB1 levels by $19.3 \%$ within $24 \mathrm{~h}$ (Doyle et al., 1982).

Deamination. Adding $\mathrm{NaNO}_{2}$ to an aqueous medium deaminates $\mathrm{FB} 1$ and so reduces its toxicity (Lemke et al., 2001b).

\section{Transformation by microorganisms and enzymes}

The use of chemical or physical processes to decontaminate food is limited by high costs, a loss of food's nutritional quality, poor efficiency, low specificity and consumer reticence toward chemical methods. Thus, scientists have come to favor the detoxification of mycotoxins by biological transformation which can be defined as the degradation or enzymatic transformation of mycotoxins (by full microorganisms or enzymes) in less toxic compounds.

A wide range of microorganisms belonging to the bacteria, moulds and yeasts have shown their capacity to biotransform mycotoxins. Such microbes act in the intestinal tract of animals prior to the resorption of the mycotoxins.

AFB1 transformation. Removal and detoxification of AFB1 by transformation have been investigated for many years. Unfortunately, few studies have led to the identification of the transformed product. One of the first bacteria studied for its capacity to remove AFB1 was 
Flavobacterium aurantiacum (also known as Nocardia corynebacteriodes). Its crude extract was shown to remove AFB1 (Ciegler et al., 1966; Hao and Brackett, 1989). Further studies had shown that the transformation did not lead to a toxic product (Lillehoj et al., 1967) and that an intracellular enzyme was involved (Smiley and Draughon, 2000). Guan et al. (2008) succeeded in obtaining Stenotrophomonas maltophilia isolates on selective medium containing only coumarin (chemical component of AFB1 nucleus) as the carbon source and showed that it is capable of transforming AFB1. Bacillus subtilis was also able to detoxify AFB1-contaminated feed and thus facilitate animal growth rate (Kubo, 1996; Petchkongkaew et al., 2008). Actinomyceta like Mycobacterium fluoranthenivorans was shown to remove AFB1 from contaminated media (Hormisch et al., 2004; Teniola et al., 2005). Teniola et al. (2005) succeeded in isolating extracellular enzymes from Rhodococcus erythropolis, responsible for the transformation of AFB1. Moreover, Alberts et al. (2006) observed the elimination of toxicity using the Ames test after transformation. Nakazato et al. (1990) and later Shantha (1999) observed the removal of AFB1 by moulds but no transformation product was observed. Extracellular enzymes from the macroscopic fungus Pleurotus ostreatus were shown to be able to cleave the AFB1 lactone ring Motomura et al. (2003) leading to a loss of toxicity. Armillariella tabescens is able to open the AFB1 difuran cycle (Liu et al., 1998, 2001).

OTA transformation. Certain bacteria, moulds, yeasts and plants are able to transform OTA. Amoung these microorganisms, many transform OTA into OTa (Galtier and Alvinerie, 1976; Kiessling et al., 1984; Hwang and Draughon, 1994; Wegst and Lingens, 1983 ; Skrinjar et al., 1996; Abrunhosa et al., 2002; Péteri et al., 2007), a less toxic compound. This transformation leads to a formation of phenylalanine (Figure 1). Moulds like Aspergillus, Rhyzopus, Penicillium species are particularly effictive at removing OTA (Abrunhosa et al., 2002; Bejaoui et al., 2006; Varga et al., 2000). Aureobasidium pullulans was used as a biocontrol agent in wine, preventing OTA accumulation in grapes and decreasing the aspergillosis symptom (De Felice et al., 2008). Plants like wheat and maize (Ruhland et al., 1996) or fungi like P. ostreatus (Engelhardt, 2002) are able to remove OTA but no transformation products have been identified. Trichosporon mycotoxinivorans is a microorganism that has been developed into a commercial product for detoxifying OTA in animal feed (Molnar et al., 2004). Total transformation of OTA to OTa occurred in $2.5 \mathrm{~h}$. Moreover, Schatzmayr et al. (2003, 2006) showed that the toxic effects of OTA could be alleviated by the addition of this yeast to chicken diet. The main microorganisms which transform OTA into Ota use carboxypeptidases (EC 3.4.17.1). Purified enzymes are able to cleave OTA and have been characterized (Stander et al., 2000; Abrunhosa et al., 2006).

ZEA transformation. ZEA can be transformed into an oxydised compound such as zearalanone, hydroxyl such as $\alpha$ and $\beta$ ZEA, methyl compounds, gluco- or sulfo-conjugates 
and hydrolysed compounds (Table 1) by bacteria, yeasts, moulds or plants (El-Sharkawy and Abul-Hajj; 1987a, b, 1988). The transformation of ZEA to a-zéaralénol (McMullen, 1977; Kiessling et al., 1984; Kamimura, 1986; Böswald et al., 1995) does not lead to actual detoxification since this product has an oestrogenic activity even higher than that of ZEA (Minervini et al., 2005, Fitzpatrick et al., 1989). A proteic sequence of a ZEA esterase transforming ZEA into decarboxylated ZEA from a Rhodococcus or Nocardia species has been patented for insertion in transgenic plants (Duvick and Rood, 2000; Karlovsky et al., 2003). Trichosporon mycotoxinivorans is also able to decarboxylate ZEA (Molnar et al., 2004; Vekiru et al., 2010). Some conjugates can also be formed from ZEA, such as ZEAglucoside (El-Sharkawy and Abul-Hajj, 1987a; Kamimura, 1986) and ZEA-sulfate (EI Sharkawy et al., 1991; Plasencia and Mirocha, 1991). Recently, Jard et al. (2010), using a MCF-7 cell line, showed that ZEA sulfonation leads to a reduction in oestrogenic toxicity. This confirms the study done by Plasencia and Mirocha (1991), using the uterus weight test, showing a decline in toxicity by ZEA sulfonation. However, it has not been proven that sulfonation or glycosylation leads effectively to a detoxification insofar as hydrolysis of this conjugate could occur in the digestive tract. Moreover, plants are able to transform ZEA into ZEA-glycoside (Schneweis et al., 2002) leading to masked mycotoxins which could not be measured but could be released by feeding with contaminated plants. Other degradation products have been observed, including decarboxylated and hydrolysed compounds (ElSharkawy and Abul-Hajj, 1988; Kakeya et al., 2002; Takahashi-Ando et al., 2002; Igawa et al., 2007; Duvick and Rood, 2000; Karlovsky et al., 2003). The corresponding gene of this enzymatic activity was cloned and transfered to different organisms like yeast (TakahashiAndo et al., 2005) and plants (Kakeya et al., 2002; Takahashi-Ando et al., 2002; Igawa et al., 2007). Utermark and Karlovsky (2007) showed that ZEA lactonohydrolase from Clonostachys rosea (El-Sharkawy and Abul-Hajj, 1988) prevents the growth inhibition observed for others types of fungi growing on ZEA-contaminated media. Gromadzka et al. (2009) showed that this fungus could be used as a biocontrol agent for mycotoxin production in cereals. Pseudomonas sp., bacteria from soil are able to remove ZEA (EI-Deeb, 2005). The product was not identified but was assumed to be less toxic than ZEA. Megharaj et al. (1997) showed that a mixed culture from soil was able to remove ZEA. No transformation product was observed. An unidentified bacterium from pig intestine was also able to remove ZEA (Kollarczik et al., 1994). Some microorganisms have the capacity to remove ZEA producing different derived compounds. For example, El Sharkawy et al. (1991) identified $26 \%$ of ZEA-sulfate and $18 \%$ of $\alpha$-ZOL after a ZEA transformation by Rhyzopus. An enzyme from Pseudomonas $s p$. responsible for the transformation into a less toxic product is encoded by a plasmid (Skrinjar et al., 1996). Cheng et al. (2006) studied an enzyme able to transform ZEA but its origin and transformation product(s) are unknown. 
Trichothecenes transformation. Trichothecenes transformation by microorganisms was reviewed by Zhou et al. (2008) and He et al. (2010). The 12,13-epoxy cycle of DON and of T2 toxin seems to be the part of the molecule which is responsible for the toxicity. By opening this cycle, the mycotoxin become less toxic (Swanson et al., 1988; Zhou et al., 2008).

Some studies report a transformation of DON by mixed cultures of microorganisms but few of these have been identified. The two main metabolites are de-epoxydised DON (Kollarczik et al., 1994; Young et al., 2007; Yoshizawa et al., 1983; Côté et al., 1986; He et al., 1992; Swanson et al., 1988; King et al., 1984) and 3-keto-DON (Young et al., 2007; Binder and Binder, 2004; Shima et al., 1997). The chemical structures of these DON metabolites are presented on Table 2. Both are less toxic than DON. For example, Shima et al. (1997) observed a weaker immunosuppressive activity for 3-keto-4-DON produced by Agrobacterium-Rhizobium E 3-39 than for DON.

The Eubacterium sp. strain BBSH 797 has been developed into a commercial product Mycofix plus (Biomin $\AA$ ) for detoxifying trichothecenes in animal feed (Schatzmayr et al., 2006). An enzyme named MDE (mycotoxin-degrading enzyme), whose origin is not specified is able to degrade DON with ZEA (Cheng et al., 2006). Some transformation products have not yet been identified (Binder and Binder, 2004; Völkl et al., 2004; Guan et al., 2009). Among these transformations, one was done by a bacterium from fish intestine, achieving $100 \%$ removal in $96 \mathrm{~h}$.

Few studies exist concerning the transformation of T-2 and HT-2 toxins. Some metabolites were identified to be de-acetylate and de-epoxydised T-2 (Table 3). Some microorganisms were able to transform T-2 toxin into HT-2 toxin but this did not lead to detoxification (Fuchs et al., 2002; Swanson et al., 1988). Bacteria isolated by enrichment from contaminated soil or water can transform T-2 toxin into T-2 triol and T-2 tetraol (Beeton and Bull, 1989). A similar transformation was observed for carboxyl esterase isolated from rat liver (Johnsen et al., 1986). Some moulds can transform T-2 toxin but the transformation products were not identified (Jesenska and Sajbidorova, 1991). The metabolism of T-2 toxin was elucidated by Swanson et al. (1988) and Beeton and Bull (1989). It includes a sequence of different steps: the molecule is first transformed into HT-2 toxin by deacetylation. A second deacetylation was observed to transform HT-2 toxin into T-2 triol, 20 times less toxic than the T-2 toxin (Ueno et al., 1983). Finally, this molecule is transformed into T-2 tetraol. Other metabolites observed are the de-epoxyed metabolites cited previously (Table 3).

Fumonisin B1 transformation. The primary amine of FB1 confers its toxicity. The deamination of this molecule greatly reduces its toxicity. Very few studies have been done on the biological degradation of FB1. The main microorganism able to degrade FB1 is the black yeast Exophiala spinifera. The different metabolites produced by this yeast are presented in Table 4. The transformation of FB1 into AP1 is performed by an extracellular carboxylesterase. This enzyme has been cloned and was shown to be efficient in transgenic 
maize, as the plant became resistant to fumonisine (Duvick et al., 2003). Other enzymes are involved in FB1 degradation and some derived products have been characterised (Blackwell et al., 1999). A patent was taken out in 2003 (Duvick et al., 2003) for esterase used to detoxify fumonisines.

\section{Conclusion}

Although there are many publications on the removal of mycotoxins by adsorption and transformation, their applications in detoxification have been limited.

Chemical treatment for the detoxification of aflatoxins using ammonia is the only application currently licensed in the United States. Chemical treatment is not allowed within the European Union for products used by humans (EU Commission Regulation, 2001). Recourse to chemical transformation may lead to toxic derivatives in the treated products. These sideeffects limit their use in the human and animal food chains (Kabak et al., 2006) with the decreased interest in chemical transformations, interest has been increasingly focused on adsorption or transformation of mycotoxins. Adsorption by yeast cell walls added to feed is used most commonly in the industrial context. Legislation is changing to allow the marketing of mycotoxin binders. Up to now, these products have been sold for other applications such as increasing antioxydising activity. It has proved difficult for governments to legislate on this topic without encouraging suppliers to sell contaminated commodities. Mycotoxin adsorption is quite well documented and was tested in vitro in a gastrointestinal tract which has enabled us to better determine the stability of the binder-mycotoxin complex (Avantaggiatto et al., 2004, 2007).

Transformation of mycotoxins for detoxification is not much used in industry. This may be due to the lack of information about the transformation mechanisms, the toxicity of products derived from transformation, and the effect of transformation reactions on the nutritional value of food and feed. In some cases, transformation products have not been identified and so cannot be used in industrial processes. The stability of transformations and their potential side-effects should be investigated.

Indeed, the use of a microorganism for detoxifying mycotoxins in feed requires the observance of certain conditions:

- The first step is identification of a microorganism's degradation potential;

- Each product must be identified and its toxicity must be tested, using different methods if possible;

- Derived products must be non-toxic;

- Biotransformation must be fast and microorganisms must be efficient at different levels of oxygen or $\mathrm{pH}$, especially when transformation takes place during digestion;

- Microorganisms must be non-pathogenic;

- Microorganisms must be active in a complex environment and not inhibited by nutrients; 
- The efficiency of the transformation must be assessed in vivo.

The use of microbial detoxification agents (living cells) in the human food and animal feed industries seems to be diminishing on account of regulatory, toxicological and consumer considerations. Thus, applications of detoxification enzymes and genes can represent alternative detoxification methods. Some interesting studies have been carried out using molecular engineering techniques to obtain genes (Takahashi-Ando et al., 2004). Such genes were obtained, cloned and incorporated into microorganisms to produce recombinant enzymes that are suitable for industrial-scale enzyme production and purification (Althali and Deeb, 2009).

Today, chemical transformation is no longer suitable for detoxifying mycotoxin-contaminated food and feed. Mycotoxin binding may be a feasible industrial solution because of its relative low cost compared to biotransformation. However, this technique can lead to negative sideeffects. Indeed, adsorption could be reversible as a mycotoxin could desorb in the digestive tract, and adsorption can be non-specific thus decreasing overall nutritional value (Phillips et al., 2008). Mycotoxin transformation appears to offer great interest as a technique for increasing the quality of food and feed. Studies involving biotransformation have led to encouraging results. But, further studies must be done to ensure the safety of this method. The transformation of mycotoxins in food and feed promises to be a very reliable technique for enhancing food safety and eliminating all negative effects of the mycotoxins present.

\section{Acknowledgements}

The authors especially thank "Evialis" (Saint-Nolff, France) for its financial support.

\section{References}

Abbes S, Ouanes Z, Ben Salah-Abbes J, Abdel-Wahhab MA, Oueslati R, Bacha H. 2007. Preventive role of aluminosilicate clay against induction of micronuclei and chromosome aberrations in bone-marrow cells of Balb/c mice treated with Zearalenone. Mutat Res-Gen Toxicol Environ Muta. 631(2): 85-92.

Abd Alla ESAM. 1997. Zearalenone: Incidence, toxigenic fungi and chemical decontamination in Egyptian cereals. Food Nahrung. 41: 362- 365.

Abrunhosa L, Santos L, Venancio A. 2006. Degradation of ochratoxin A by proteases and by a crude enzyme of Aspergillus niger. Food Biotechnol. 20(3): 231-242.

Afssa, 2009. Évaluation des risques liés à la présence de mycotoxines dans les chaînes alimentaires humaine et animale. Rapport final.

Afifi AF, Foaad MA, Fawzi EM. 2003. Effect of gamma irradiation on elimination of aflatoxins produced by apple mycoflora in apple fruits. Acta Microbiol Pol. 52: 379-86.

Afolabi CG, Bandyopadhyay R, Leslie JF, Ekpo EJA. 2006. Effect of sorting on incidence and occurrence of fumonisins and Fusarium verticillioides on maize from Nigeria. J Food Prot. 69(8): 2019-2023. 
Afriyie-Gyawu E, Wang Z, Ankrah NA, Xu L, Johnson NM, Tang L, Guan H, Huebner HJ, Jolly PE, Ellis WO, Taylor R, Brattin B, Ofori-Adjei D, Williams JH, Wang JS, Phillips TD. 2008. NovaSil clay does not affect the concentrations of vitamins $A$ and $E$ and nutrient minerals in serum samples from Ghanaians at high risk for aflatoxicosis. Food Addit Contam Part A Chem Anal Control Expo Risk Assess. 25(7):872-884.

Alberts JF, Engelbrecht Y, Steyn PS, Holzapfel WH, Van Zyl WH. 2006. Biological degradation of aflatoxin B-1 by Rhodococcus erythropolis cultures. Int J Food Microbiol. 109(1-2): 121-126.

Alegakis AK, Tsatsakis AM, Schtilman MI, Lysovenko DL, Vlachonikolis IG. 1999. Deactivation of mycotoxins. I. An in vitro study of zearalenone adsorption on new polymeric adsorbents. J Environ Sci Heal B. 34(4): 633-644.

Altalhi D, El-Deeb B. 2009. Localization of zearalenone detoxification gene(s) in pZEA-1 plasmid of Pseudomonas putida ZEA-1 and expressed in Escherichia coli. J Hazard Mater. 161: 1166-1172.

Aly SE, Abdel-Galil MM, Abdel-Wahhab MA. 2004. Application of adsorbent agents technology in the removal of aflatoxin B-1 and fumonisin B-1 from malt extract. Food and Chem Toxicol. 42(11): 1825-1831.

Angioni A, Caboni P, Garau A, Farris A, Orro D, Budroni M, Cabras P. 2007. In vitro interaction between ochratoxin $A$ and different strains of Saracchomyces cerevisiae and Kloeckera apiculata. J Agric Food Chem. 55(5): 2043-2048.

Aravind KL, Patil VS, Devegowda G, Umakantha B, Ganpules P. 2003. Efficacy of esterified glucomannan to counteract mycotoxicosis in naturally contaminated feed on performance and serum biochemical and hematological parameters in broilers. Poultry Sci. 82(4): 571576.

Arino A, Juan T, Estopanan G, Gonzalez-Cabo JF. 2007. Natural occurrence of Fusarium species, fumonisin production by toxigenic strains, and concentrations of fumonisins $B$ [1] and $\mathrm{B}[2]$ in conventional and organic maize grown in Spain. J Food Prot. 70(1): 151-156.

Avantaggiato G, Havenaar R, Visconti A. 2003. Assessing the zearalenone-binding activity of adsorbent materials during passage through a dynamic in vitro gastrointestinal model. Food Chem Toxicol. 41(10): 1283-1290.

Avantaggiato G, Havenaar R, Visconti A. 2004. Evaluation of the intestinal absorption of deoxynivalenol and nivalenol by an in vitro gastrointestinal model, and the binding efficacy of activated carbon and other adsorbent materials. Food Chem Toxicol. 42(5): 817-824.

Avantaggiato G, Solfrizzo M Visconti A. 2005. Recent advances on the use of adsorbent materials for detoxification of Fusarium mycotoxins. Food Addit Contam. 22(4): 379-388.

Avantaggiato G, Havenaar R, Visconti A. 2007. Assessment of the multi-mycotoxin-binding efficacy of a carbon/aluminosilicate-based product in an in vitro gastrointestinal model. J Agri Food Chem. 55(12): 4810-4819. 
Awad WA, Ghareeb K, Bohm J, Zentek J. 2010. Decontamination and detoxification strategies for the Fusarium mycotoxin deoxynivalenol in animal feed and the effectiveness of microbial biodegradation. TFAC. 27(4):510-520.

Babtista AS, Horii J, Calori-Domingues MA, Da Gloria EM, Salgado JM, Vizioli MR. 2002. Thermolysed and active yeast to reduce the toxicity of aflatoxin. Sci Agric. 59:257-260.

Basmacioglu H, Oguz H, Ergul M, Col R, Birdane YO. 2005. Effect of dietary esterified glucomannan on performance,serum biochemistry and haematology in broilers exposed to aflatoxin. Czech J Anim Sci. 50:31-39.

Bauer J. 1994. Moglichkeiten zur Entgiftung mykotoxinhaltiger Futtermittel. Monatsh Veterinarmed. 49:175-181.

Beeton S, Bull AT. 1989. Biotransformation and detoxification of T-2 toxin by soil and freshwater bacteria. Appl Environ Microbiol. 55(1): 190-197.

Bejaoui H, Mathieu F, Taillandier P, Lebrihi A. 2004. Ochratoxin A removal in synthetic and natural grape juices by selected oenological Saccharomyces strains. J Appl Microbiol. 97(5) : 1038-1044.

Bejaoui H, Mathieu F, Taillandier P, Lebrihi A. 2005. Conidia of black Aspergilli as new biological adsorbents for ochratoxin A in grape juices and musts. J Agric Food Chem. 53(21): 8224-8229.

Bejaoui $H$, Mathieu F, Taillandier P, Lebrihi A. 2006. Black aspergilli and ochratoxin A production in French vineyards. Int J Food Microbiol. 111 (S1): S46-52.

Bennett GA, Anderson RA. 1978. Distribution of aflatoxin and/or zearalenone in wet-milled corn products: a review. J Agric Food Chem. 26(5): 1055-1060.

Binder EM, Binder J. 2004. Strain of Eubacterium that detoxyfies trichothecenes. International patent US 6794175, Erber Aktiengesellschaft.

Blackwell BA, Gilliam JT, Savard ME, Miller DJ, Duvick JP. 1999. Oxidative deamination of hydrolyzed fumonisin $\mathrm{B}(1)(\mathrm{AP}(1))$ by cultures of Exophiala spinifera. Nat Toxins. 7: 31-38.

Böswald C, Engelhardt G, Vogel H, Wallnöfer PR. 1995. Metabolism of the Fusarium mycotoxins zearalenone and deoxynivalenol by yeast strains of technological relevance. Nat Toxins. 3: 138-44.

Bren U, Guengerich, FP, Mavri J. 2007. Guanine alkylation by the potent carcinogen aflatoxin B1: quantum chemical calculations. Chem Res Toxicol. 20: 1134-1140.

Bretz M, Beyer M, Cramer B, Knecht A, Humpf H. 2006. Thermal degradation of the Fusarium mycotoxin deoxynivalenol. J Agric Food Chem. 54: 6445- 6451.

Bueno DJ, Di Marco L, Olivier G, Bardon A. 2005. In vitro binding of zearalenone to different adsorbents. J Food Prot. 68(3): 613-615.

Bueno DJ, Casale CH, Pizzolitto RP, Salvano MA, Oliver G. 2007. Physical adsorption of aflatoxin B1 by lactic acid bacteria and Saccharomyces cerevisiae : a theoritical model. J Food Prot. 70(9): 2148-2154. 
Bullerman LB, Bianchini A. 2007. Stability of mycotoxins during food processing. Int J Food Microbiol. 119(1-2): 140-146.

Burges HD, Burrell ND. 1964. Cooling of bulk grain in the British climate to control storage insects and to improve keeping quality. J Sci Food Agric. 15: 32-50.

Bursian SJ, Aulerich RJ, Cameron JK, Ames NK, Steficek BA. 1992. Efficacy of hydrated sodium calcium aluminosilicate in reducing the toxicity of dietary zearalenone to mink. $\mathrm{J} \mathrm{Appl}$ Toxicol. 12(2): 85-90.

Bursian SJ, Mitchell RR, Yamini B, Fitzgerald SD, Murphy PA, Fernandez G, Rottinghaus GE, Moran L, Leefers K, Choi I. 2004. Efficacy of a commercial mycotoxin binder in alleviating effects of ochratoxin A, fumonisin B-1, moniliformin and zearalenone in adult mink. Vet Hum Toxicol. 46(3): 122-129.

Canadas D. 2006. Evaluation du procédé Oxygreen® pour son potentiel de décontamination en ochratoxine $A$ du blé. Les effets toxiques liés à une exposition subchronique à l'ochratoxine A sont-ils atténués ?. Thèse doctorale de l'Institut National Polytechnique de Toulouse.

Carson MS, Smith TK. 1983a. Role of bentonite in prevention of T-2 toxicosis in rats. J Anim Sci. 57(6): 1498-1506.

Carson MS, Smith TK. 1983b. Effect of feeding alfalfa and refined plant fibres on the toxicity and metabolism of T-2 toxin in rats. J Nutr. 113(2): 304-313.

CAST. 2003. Mycotoxins: Risks in plant, animal, and human systems; Task Force Report 139; Niyo K, ed. Council for Agricultural Science and Technology, Ames, lowa, USA, p. 1199.

Cazzaniga D, Basilico JC, Gonzalez RJ, Torres RL, De Greef DM. 2001. Mycotoxins inactivation by extrusion cooking of corn flour. Lett Appl Microbiol. 33(2): 144-147.

Cecchini F, Morassut M, Garcia Moruno E, Di Stefano R. 2007. Influence of yeast strain on ochratoxin A content during fermentation of white and red must. Food Microbiol. 23(5): 411 417.

Champeil A, Fourbet JF, Doré T, Rossignol L. 2004. Influence of cropping system on Fusarium head blight and mycotoxin levels in winter wheat. Crop Protection. 23(6): 531-537. Cheng YH, Weng CF, Chen BJ, Chang MH. 2006. Toxicity of different Fusarium mycotoxins on growth performance, immune responses and efficacy of a mycotoxin degrading enzyme in pigs. Anim Res. 55(6): 579-590.

Chowdhury SR, Smith TK. 2004. Effects of feeding blends of grains naturally contaminated with Fusarium mycotoxins on performance and metabolism of laying hens. Poult Sci. 83(11): 1849-1856.

Ciegler A, Lillehoj EB, Peterson RE, Hall HH. 1966. Microbial Detoxification of Aflatoxin. Appl Microbiol. 14(6): 934-939.

Clements MJ, White DG. 2004. Identifying sources of resistance to aflatoxin and fumonisin contamination in corn grain. J Toxicol-Toxin Rev. 23(2-3): 381-396. 
Codex alimentarius. 2003. Code of practice for the prevention and reduction of mycotoxin contamination in cereals, including annexes on ochratoxin A, zearalenone, fumonisins and trichothecenes. CAC/RCP 51-2003

Côté LM, Nicoletti J, Swanson SP, Buck WB. 1986. Production of deepoxydeoxynivalenol (DOM-I), a metabolite of deoxynivalenol, by in vitro rumen incubation. J Agr Food Chem. 34(3): 458-460.

Dakovic A, Tomasevic-Canovic M, Rottinghaus GE, Dondur V, Masic Z. 2003. Adsorption of ochratoxin A on octadecyldimethyl benzyl ammonium exchanged-clinoptilolite-heulandite tuff. Colloids Surf B-Biointerfaces 30(1-2): 157-165.

Dakovic A, Tomasevic-Canovic M, Dondur V, Rottinghaus GE, Medakovic V, Zaric S. 2005. Adsorption of mycotoxins by organozeolites. Colloids Surf B-Biointerfaces. 46(1): 20-25.

Dakovic A, Matijasevic S, Rottinghaus GE, Dondur V, Pietrass T, Clewett CFM. 2007. Adsorption of zearalenone by organomodified natural zeolitic tuff. J Colloid Interface Sci. 311(1): 8-13.

Dänicke S, Valenta H, Gareis M, Lucht HW, von Reichenbach H. 2005. On the effects of a hydrothermal treatment of deoxynivalenol (DON)-contaminated wheat in the presence of sodium metabisulphite $\left(\mathrm{Na}_{2} \mathrm{~S}_{2} \mathrm{O}_{5}\right)$ on DON reduction and on piglet performance. Anim Feed Sci Technol. 118(1-2): 93-108.

Decker WJ, Corby DG. 1980. Activated charcoal adsorbs aflatoxin B1. Vet Hum Toxicol. 22(6): 388-389.

De Felice DV, Solfrizzo M, De Curtis F, Lima G, Visconti A, Castoria R. 2008. Strains of Aureobasidium pullulans can lower ochratoxin A contamination in wine grapes. Phytopathology. 98: 1261-1270.

Del Prete V, Rodriguez H, Carrascosa AV, de las Rivas B, Garcia-Moruno E, Muñoz R. 2007. In vitro removal of ochratoxin A by wine lactic acid bacteria. J Food Prot 70(9): 215560.

Diaz DE, Hagler WM, Blackwelder JT, Eve JA, Hopkins BA, Anderson KL, Jones FT, Whitlow LW. 2004. Aflatoxin Binders II: Reduction of aflatoxin M1 in milk by sequestering agents of cows consuming aflatoxin in feed. Mycopathologia. 157(2): 233-241.

Döll S, Dänicke S. 2004. In vivo detoxification of fusarium toxins. Arch Anim Nutr. 58(6): 419441.

Döll S, Dänicke S, Valenta H, Flachowsky G. 2004. In vitro studies on the evaluation of mycotoxin detoxifying agents for their efficacy on deoxynivalenol and zearalenone. Arch Anim Nutr. 58(4): 311-324. 
Dorner JW, Cole RJ. 2002. Effect of application of nontoxigenic strains of Aspergillus flavus

and $A$. parasiticus on subsequent aflatoxin contamination of peanuts in storage. $\mathrm{J}$ Stored Prod Res. 38: 329-339.

Doyle MP, Applebaum RS, Brackett RE, Marth EH. 1982. Physical, chemical and biological degradation of mycotoxins in foods and agricultural commodities. J Food Protect. 45: 964971.

Driehuis F, Oude-Elferink SJ. 2000. The impact of the quality of silage on animal health and food safety: a review. Veterinary Quaterly. 22: 212-216.

Dupuy J, Le Bars P, Boudra A, Le Bars J. 1993. Thermostability of fumonisin B1, a mycotoxin from Fusarium moniliforme, in corn. Appl Environ Microbiol. 59: 2864- 2867.

Duvick J, Rood TA. 2000. Zearalenone detoxification compositions and methods. US patent 6074838, Pioneer Hi-Bred International, Inc. (Des Moines, IA).

Duvick J, Bowen B, Gilliam J, Maddox J, Rood T, Wang X. 2003. Fumonisin detoxification compositions and methods. US patent 6670189, Pioneer Hi-Bred International, Inc. (Des Moines, IA).

Dvorska JE, Surai PF. 2001. Effects of T-2 toxin, zeolite and Mycosorb on antioxidant systems of growing quail. Asian-Australasian J Anim Sci. 14(12): 1752-1757.

Edrington TS, Kubena LF, Harvey RB, Rottinghaus GE. 1997. Influence of superactivated charcoal on the toxic effects of aflatoxin or T-2 toxin in growing broilers. Poult Sci. 76(9):1205-1211.

Edrington TS, Sarr AB, Kubena LF, Harvey RB, Phillips TD. 1996. Hydrated sodium calcium aluminosilicate (HSCAS), acidic HSCAS, and activated charcoal reduce urinary excretion of aflatoxin M1 in turkey poults. Lack of effect by activated charcoal on aflatoxicosis. Toxicol Lett. 89(2): 115-122.

EFSA. 2009. Review of mycotoxin-detoxifying agents used as feed additives: mode of action, efficacy and feed/food safety. Scientific report CFP/EFSA/FEEDAP/2009/01.

El-Deeb BA. 2005. Isolation and characterization of soil bacteria able to degrade zearalenone. J Bot. 32, 3-30.

El-Nezami H, Kankaanpää P, Salminen S, Ahokas J. 1998. Physicochemical alterations enhance the ability of dairy strains of lactic acid bacteria to remove aflatoxin from contaminated media. J Food Prot. 61(4): 466-468.

El-Nezami H, Mykkänen H, Kankaanpää P, Salminen S, Ahokas J. 2000. Ability of Lactobacillus and Propionibacterium strains to remove aflatoxin $B$, from the chicken duodenum. J Food Prot. 63(4):549-552. 
El-Nezami HS, Chrevatidis A, Auriola S, Salminen S, Mykkanen H. 2002a. Removal of common Fusarium toxins in vitro by strains of Lactobacillus and Propionibacterium. Food Addit Contam. 19(7): 680-686.

El-Nezami H, Polychronaki N, Salminen S, Mykkänen H. 2002b. Binding rather than metabolism may explain the interaction of two food-grade Lactobacillus strains with zearalenone and its derivative alpha-zearalenol. Appl Environ Microbiol. 68(7): 3545-3549.

El-Nezami H, Polychronaki N, Yuan Kun L, Haskard C, Juvonen R, Salminen S, Mykkänen H. 2004. Chemical moieties and interactions involved in the binding of zearalenone to the surface of Lactobacillus rhamnosus strains GG. J Agric Food Chem. 52(14): 4577-4581.

Engelhardt G. 2002. Degradation of ochratoxin $a$ and $b$ by the white rot fungus Pleurotus ostreatus. Mycotox Res. 18(1): 37-43.

El Sharkawy SH, Abul-Hajj Y. 1987a. Microbial transformation of zearalenone 1. Formation of zearalenone 4-b-glucoside. J Nat Prod. 50: 520-521.

El Sharkawy SH, Abul-Hajj Y. 1987b. Microbial transformation of zearalenone 2. Reduction, hydroxylation, and methylation products. J Org Chem. 53(3): 515-519.

El Sharkawy SH, Abul-Hajj Y. 1988. Microbial clivage of zearalenone. Xenobiotica. 18(4): 365-371.

El Sharkawy SH, Mustafa IS, Mohamed SA Halaweish FT. 1991. Microbial transformation of zearalenone to a zearalenone sulfate. Appl Environ Microbiol. 57(2): 449-552.

EU Commission Regulation (EC) No 466/2001 of 8 March 2001 setting maximum levels for certain contaminants in foodstuffs.

Farag RS, Rashed MM, Abo Hagger AA. 1996. Aflatoxin destruction by microwave heating. Int J Food Sci Nutr. 47: 197-208.

Fazeli MR, Hajimohammadali M, Moshkani A, Samadi N, Jamalifar H, Khoshayand MR, Vaghari E, Pouragahi S. 2009. Aflatoxin B1 binding capacity of autochthonous strains of lactic acid bacteria. J Food Prot. 72(1): 189-192.

Fernández-Surumay G, Osweiler GD, Yaeger MJ, Rottinghaus GE, Hendrich S, Buckley LK, Murphy PA. 2005. Fumonisin B-glucose reaction products are less toxic when fed to swine. J Agric Food Chem. 53(10):4264-71.

Finamore A, Britti MS, Roselli M, Bellovino D, Gaetani S, Mengheri E. 2004. Novel approach for food safety evaluation. Results of a pilot experiment to evaluate organic and conventional foods. J Agric Food Chem. 52(24): 7425-7431.

Fink-Gremmels J, Malekinejad H. 2007. Clinical effects and biochemical mechanisms associated with exposure to the mycoestrogen zearalenone. Anim Feed Sci Technol. 137(34): 326-341.

Fitzpatrick DW, Picken CA, Murphy LC, Buhr MM. 1989. Measurement of the relative affinity of zearalenone, alpha-zearalenol and beta-zearalenol for uterine and oviduct estrogen receptors in swine, rats and chickens: an indicator of estrogenic potencies. Comp Biochem Physiol Part C: Toxicol Pharmacol. 94(2): 691-694. 
Freimund S, Sauter M, Rys P. 2003. Efficient adsorption of the mycotoxins zearalenone and T-2 toxin on a modified yeast glucan. J Environ Sci Health B. 38(3): 243-255.

Fricke RF, Jorge J. 1990. Assessment of efficacy of activated charcoal for treatment of acute T-2 toxin poisoning. J Toxicol Clin Toxicol. 28(4): 421-431.

Friend DW, Trenholm HL, Young JC, Thompson B, Hartin KE. 1984. Effects of adding potential vomitoxin (deoxynivalenol) detoxicants or a $F$. graminearum inoculated corn supplement to wheat diets to pigs. Can J Anim Sci. 64:733-741.

Fuchs E, Binder EM, Heidler D, Krska R. 2002. Structural characterization of metabolites after the microbial degradation of type A trichothecenes by the bacterial strain BBSH 797 . Food Add Contamin. 19(4): 379-386.

Galtier P, Alvinerie M. 1976. In vitro transformation of ochratoxin A by animal microbioal floras. Ann Rech Vet. 7: 91-98.

Galvano F, Galofaro F, Galvana G. 1996. Occurrence and stability of aflatoxin M(1) in milk and milk products: A worldwide review. J Food Prot. 59(10): 1079-1090.

Galvano F, Pietri A, Bertuzzi T, Piva A, Chies L, Galvano M. 1998. Activated carbons: In vitro affinity for ochratoxin $A$ and deoxynivalenol and relation of adsorption ability to physicochemical parameters. J Food Prot. 61(4): 469-475.

Garcia AR, Avila E, Rosiles R, Petrone VM. 2003. Evaluation of two mycotoxin binders to reduce toxicity of broiler diets containing ochratoxin $A$ and T-2 toxin contaminated grain. Avian Dis. 47(3): 691-699.

Gaumy JL, Bailly JD, Burgat V, Guerre P. 2001. Zéaralénone: propriétés et toxicité expérimentale. Revue Méd Vét. 152: 219-234.

Glenn AE. 2007. Mycotoxigenic Fusarium species in animal feed. Anim Feed Sci Technol. 137(3-4): 213-240.

Gromadzka K, Chelkowski J, Popiel D, Kachlicki P, Kostecki M, Glinski P. 2009. Solid substrate bioassay to evaluate the effect of Trichoderma and Clonostachys on the production of zearalenone by Fusarium species. World Mycotoxin Journal. 2(1): 45-52.

Guan S, Ji C, Zhou T, Li J, Ma Q, Niu T. 2008. Aflatoxin B(1) degradation by Stenotrophomonas maltophilia and other microbes selected using coumarin medium. Int $\mathrm{J}$ Mol Sci. 9(8): 1489-1503.

Guan S, He JW, Young JC, Honghui Z, Li XZ, Cheng J, Ting Z. 2009. Transformation of trichothecene mycotoxins by microorganisms from fish digesta. Aquaculture. 290(3-4): 290295.

Guerre P. 2000. Interest of the treatments of raw materials and usage of adsorbents to decontaminate animal food containing mycotoxins. Rev Med Vet. 151(12): 1095-1106.

Hao DYY, Brackett RE. 1989. Growth and survival of Flavobacterium Aurantiacum in peanut Milk J Food Prot. 52: 165-168.

Haskard C, Binnion C, Ahokas J. 2000. Factors affecting the sequestration of aflatoxin by Lactobacillus rhamnosus strain GG. Chem Biol Interact. 128(1): 39-49. 
Haskard CA, El-Nezami HS, Kankaanpä PE, Salminen S, Ahokas JT. 2001. Surface binding of aflatoxin B(1) by lactic acid bacteria. Appl Environ Microbiol. 67(7): 3086-3091.

Hatch RC, Clark JD, Jain AV, Weiss R. 1982. Induced acute aflatoxicosis in goats: treatment with activated charcoal or dual combinations of oxytetracycline, stanozolol, and activated charcoal. Am J Vet Res. 43(4):644-8.

He P, Young LG Forsberg C. 1992. Microbial transformation of deoxynivalenol (vomitoxin). Appl Environ Microbiol. 58(12): 3857-3863.

He J, Zhou T, Young JC, Boland GJ, Scott PM. 2010. Chemical and biological transformations for detoxification of trichothecene mycotoxins in human and animal food chains: a review. Trends in Food Sci Technol. 21(2): 67-76.

Heathcote JG and Hibbert JR. 1978. Aflatoxins : Chemical and biological aspect. Elsevier, New York. pp.173-186.

Hormisch D, Brost I, Kohring GW, Giffhorn F, Kroppenstedt RM, Stackebradt E, Färber P, Holzapfel WH. 2004. Mycobacterium fluoranthenivorans sp nov., a fluoranthene and aflatoxin B-1 degrading bacterium from contaminated soil of a former coal gas plant. Syst Appl Microbiol. 27(6): 653-660.

Huff WE, Kubena LF, Harvey RB, Phillips TD. 1992. Efficacy of Hydrated Sodium Calcium Aluminosilicate to Reduce the Individual and Combined Toxicity of Aflatoxin and OchratoxinA. Poul Sci. 71(1): 64-69.

Huwig A, Freimund S, Käppeli O, Dutler H. 2001. Mycotoxin detoxification of animal feed by different adsorbents. Toxicol Letters. 122(2): 179-188.

Hwang CA, Draughon FA. 1994. Degradation of ochratoxin A by Acinetobacter calcoaceticus. J Food Prot. 57: 410-414

Igawa T, Takahashi-Ando N, Ochiai N, Ohsato S, Shimizu T, Kudo T, Yamaguchi I, Kimura M. 2007. Reduced contamination by the Fusarium mycotoxin zearalenone in maize kernels through genetic modification with a detoxification gene. Appl Environ Microbiol. 73(5): 16221629.

Jansen van Rensburg C, Van Rensburg CE, Van Ryssen JB, Casey NH, Rottinghaus GE. 2006. In vitro and in vivo assessment of humic acid as an aflatoxin binder in broiler chickens. Poult Sci. 85(9) : 1576-1583.

Jard G, Liboz T, Mathieu F, Guyonvarc'h A, Lebrihi A. 2009. Adsorption of zearalenone by Aspergillus japonicus conidia: new trends for biological ZON decontamination in animal feed. World Mycotoxin J. 2: 391-397.

Jard G, Liboz T, Mathieu F, Guyonvarc'h A, André F, Delaforge M, Lebrihi A. 2010. Transformation of zearalenone to zearalenone sulfate by Aspergillus sp. World Mycotoxin J. 3: 183-191.

Jesenska Z, Sajbidorova I. 1991. T-2 toxin degradation by micromycetes. J Hyg Epidemiol Microbiol Immunol. 35(1): 41-49. 
Johnsen H, Odden E, Lie O, Johnsen BA, Fonnum F. 1986. Metabolism of T-2 toxin by rat liver carboxylesterase. Biochem Pharmacol. 35(9) : 1469-1473.

Jouany JP. 2007. Methods for preventing, decontaminating and minimizing the toxicity of mycotoxins in feeds. Anim Feed Sci Technol. 137(3-4): 342-362.

Kabak B, Dobson ADW, Var I. 2006. Strategies to prevent mycotoxin contamination of food and animal feed: A review. Crit Rev Food Sci Nutr. 46(8): 593-619.

Kabak B. 2009. The fate of mycotoxins during thermal food processing. J Sci Food Agric. 89(4): 549-554.

Kakeya H, Takahashi-Ando N, Kimura M, Onose R, Yamaguchi I, Osada H. 2002. Biotransformation of the mycotoxin, zearalenone, to a non-estrogenic compound by a fungal strain of Clonostachys sp. Biosci Biotechnol Biochem. 66(12): 2723-2726.

Kamimura H. 1986. Conversion of zearalenone to zearalenone glycoside by Rhizopus sp.. Appl Environ Microbiol. 52(3): 515-519.

Karaman M, Basmacioglu H, Ortatatli M, Oguz H. 2005. Evaluation of the detoxifying effect of yeast glucomannan on aflatoxicosis in broilers as assessed by gross examination and histopathology. Br Poult Sci. 46(3): 394-400.

Karlovsky P, Edmund III Crane H, Gilliam JT, Maddox JR. 2003. Compositions and methods of zearalenone detoxification. US patent 20030073239, Pioneer Hi-Bred International, Inc. (Des Moines, IA).

Kerkadi A, Barriault C, Tuchweber B, Frohlich AA, Marquardt RR, Bouchardand G, Yousef IM. 1998. Dietary cholestyramine reduces ochratoxin A-induced nephrotoxicity in the rat by decreasing plasma levels and enhancing fecal excretion of the toxin. $\mathrm{J}$ Toxicol Environ Health. 3(3):231-250.

Kiessling KH, Pettersson H, Sandholm K, Olsen M. 1984. Metabolism of aflatoxin, ochratoxin, zearalenone, and three trichothecenes by intact rumen fluid, rumen protozoa, and rumen bacteria. Appl Environ Microbiol. 47(5): 1070-1073.

King RR, McQueen RE, Levesque D, Greenhalgh R. 1984. Transformation of deoxynivalenol (vomitoxin) by rumen microorganisms. J Agric Food Chem. 32(5): 1181-1183.

Kollarczik B, Gareis M, Hanelt M. 1994. In vitro transformation of the Fusarium mycotoxins deoxynivalenol and zearalenone by the normal gut microflora of pigs. Nat Toxins. 2(3): 105110.

Krebs H, Streit B, Forrer HR. 2000. Effect of tillage and Preceding crops on Fusarium infection and deoxynivalenol content of wheat, p.13. In T.Alfoldi, W Lockeretz and U. Niggli (ed.), The world grows organic. Proceedings of the 13th International IFOAM Scientific Conference. IOSPress, Basel.

Kubena LF, Harvey RB, Huff WE, Corrier DE, Phillips TD, Rottinghaus GE. 1990. Efficacy of a hydrated sodium calcium aluminosilicate to reduce the toxicity of aflatoxin and T-2 toxin. Poult Sci. 69(7): 1078-1086. 
Kubena LF, Harvey RB, Bailey RH, Buckley SA, Rottinghaus GE. 1998. Effects of a hydrated sodium calcium aluminosilicate (T-Bind) on mycotoxicosis in young broiler chickens. Poult Sci. 77(10):1502-1509.

Kubo K. 1996. Animal feed containing Bacillus subtilis FERM BP-3418 that decomposes aflatoxin. US patent 5549 890, AHC, Inc. (Maebashi, JP).

Kurtbay HM, Bekçi Z, Merdivan M, Yurdakoç K. 2008. Reduction of ochratoxin a levels in red wine by bentonite, modified bentonites, and chitosan. J Agric Food Chem. 56(7): 2541-2545.

Lee LS, Dunn JJ, DeLucca AJ, Ciegler A. 1981. Role of lactone ring of aflatoxin B1 in toxicity and mutagenicity. Experientia. 37(1):16-17.

Lemke SL, Grant PG, Phillips TD. 1998. Adsorption of zearalenone by organophilic montmorillonite clay. J Agri Food Chem. 46(9): 3789-3796.

Lemke SL, Mayura K, Ottinger SE, McKenzie KS, Wang N, Fickey C, Kubena LF, Phillips TD. 1999. Assessment of the estrogenic effects of zearalenone after treatment with ozone utilizing the mouse uterine weight bioassay. J Toxicol Environ Health A. 56(4): 283-295.

Lemke SL, Mayura K, Reeves WR, Wang N, Fickey C, Phillips TD. 2001a. Investigation of organophilic montmorillonite clay inclusion in zearalenone-contaminated diets using the mouse uterine weight bioassay. Toxicol Environ Health A. 62(4): 243-258.

Lemke SL, Ottinger SE, Ake CL, Mayura K, Phillips TD. 2001b. Deamination of fumonisin $B(1)$ and biological assessment of reaction product toxicity. Chem Res Toxicol. 14(1): 11-15. Lillehoj EB, Ciegler A, Hall HH. 1967. Aflatoxin B1 Uptake by Flavobacterium Aurantiacum and Resulting Toxic Effects. J Bacteriology. 93(1): 464-471.

Liu DL, Yao DS, Ren L, Lin M, Cheng WQ, Gu LQ. 1998. Detoxification of aflatoxin B-1 by enzymes isolated from Armillariella tabescens. Food Chem Toxicol. 36(7): 563-574.

Liu DL, Yao DS, Liang YQ, Zhou TH, Song YP, Long Z, Lin M. 2001. Production, purification, and characterization of an intracellular aflatoxin-detoxifizyme from Armillariella tabescens (E-20). Food Chem Toxicol. 39(5): 461-466.

Lovett J, Thompson RG, Boutin BK. 1975. Trimming as a means of removing patulin from fungus-rotted apples. J Assoc Off Anal Chem. 58(5): 909-911.

Madrigal-Santillán E, Madrigal-Bujaidar E, Marquez-Marquez R, Reyes A. 2006. Antigenotoxic effect of Saccharomyces cerevisiae on the damage produced in mice fed with aflatoxin B1 contaminated corn. Food Chem Toxicol. 44(12): 2058-2063.

Magan N, Aldred D. 2007. Post-harvest control strategies: Minimizing mycotoxins in the food chain. Int J Food Microbiol. 119: 131-139.

Mayura K, Abdel-Wahhab MA, McKenzie KS, Sarr AB, Edwards JF, Naguib K, Phillips TD. 1998. Prevention of maternal and developmental toxicity in rats via dietary inclusion of common aflatoxin sorbents: potential for hidden risks. Toxicol Sci. 41(2): 175-182.

McKenzie KS, Sarr AB, Mayura K, Bailey RH, Miller DR, Rogers TD, Norred WP, Voss KA, Plattner RD, Kubena LF, Phillips TD. 1997. Oxidative degradation and detoxification of mycotoxins using a novel source of ozone. Food Chem Toxicol. 35(8): 807-820. 
McMullen JR. 1977. Microbiological reduction of zearalenone and related compounds. US patent 4,004,978, IMC Chemical Group, Inc. (Terre Haute, IN).

Megharaj M, Garthwaite I, Thiele JH. 1997. Total biodegradation of the oestrogenic mycotoxin zearalenone by a bacterial culture. Lett Appl Microbiol. 24(5): 329-333.

Miazzo R, Peralta MF, Magnoli C, Salvano M, Ferrero S, Chiacchiera SM, Carvalho EC, Rosa CA, Dalcero A. 2005. Efficacy of sodium bentonite as a detoxifier of broiler feed contaminated with aflatoxin and fumonisin. Poult Sci. 84(1): 1-8.

Minnervini F, Giannoccaro A, Cavallini A, Visconti A. 2005. Investigations on cellular proliferation induced by zearalenone and its derivatives in relation to the estrogenic parameters. Toxicol Lett. 159(3): 272-283.

Molnar O, Schatzmayr G, Fuchs E, Prillinger H. 2004. Trichosporon mycotoxinivorans $s p$ nov., a new yeast species useful in biological detoxification of various mycotoxins. Syst Appl Microbiol. 27(6): 661-671.

Morgavi DP, Riley RT. 2007. An historical overview of field disease outbreaks known or suspected to be caused by consumption of feeds contaminated with Fusarium toxins. Anim Feed Sci Technol. 137(3-4): 201-212.

Motomura M, Toyomasu T, Mizuno K, Shinozawa T. 2003. Purification and characterization of an aflatoxin degradation enzyme from Pleurotus ostreatus. Microbiol Res. 158(3): 237242.

Munkvold GP. 2003. Cultural and genetic approaches to managing mycotoxins in maize. Annu Rev Phytopathol. 41: 99-116.

Muri SD, van der Voet H, Boon PE, van Klaveren JD, Brüschweiler BJ. 2009. Comparison of human health risks resulting from exposure to fungicides and mycotoxins via food. Food Chem Toxicol. 47(12): 2963-2974.

Murphy PA, Rice LG, Ross PF. 1993. Fumonisins B1, B2, and B3 content of lowa, Wisconsin, and Illinois corn and corn screenings. J Agr Food Chem. 41(2): 263-266.

Nakazato M, Morozumi S, Saito K, Fujinuma K, Nishima T, Kasai N. 1990. Interconversion of Aflatoxin-B1 and Aflatoxicol by Several Fungi. Appl Environ Microbiol. 56(5): 1465-1470.

Niderkorn V, Boudra H, Morgavi DP. 2006. Binding of Fusarium mycotoxins by fermentative bacteria in vitro. J Appl Microbiol. 101: 849-856.

Oatley JT, Rarick MD, Geun EJ, Linz JE. 2000. Binding of aflatoxin B-1 to bifidobacteria in vitro. J Food Prot. 63(8): 1133-1136.

Osborne BG, Ibe F, Brown GL, Petagine F, Scudamore KA, Banks JN, Hetmanski MT, Leonard CT. 1996. The effects of milling and processing on wheat contaminated with ochratoxin A. Food Addit Contam. 13(2): 141-153.

Parent-Massin D. 2004. Haematotoxicity of trichothecenes. Toxicol Lett. 153: 75-81.

Park DL, Lee LS, Price RL, Pohland AE. 1988. Review of the decontamination of aflatoxins by ammoniation: current status and regulation. J Assoc Off Anal Chem. 71(4): 685-703. 
Patterson R, Young LG. 1993. Efficacy of Hydrated Sodium-Calcium Aluminosilicate, Screening and Dilution in Reducing the Effects of Mold Contaminated Corn in Pigs. Can J Anim Sci. 73(3): 615-624.

Paul PA, Lipps PE, Hershman DE, McMullen MP, Draper MA, Madden LV. 2008. Efficacy of Triazole-Based Fungicides for Fusarium Head Blight and Deoxynivalenol Control in Wheat: A Multivariate Meta-Analysis. Phytopathol. 98(9): 999-1011.

Peltonen K, El-Nezami H, Haskard C, Ahokas J, Salminen S. 2001. Aflatoxin B1 binding by dairy strains of lactic acid bacteria and bifidobacteria. J Dairy Sci. 84(10): 2152-2156.

Pestka JJ. 2007. Deoxynivalenol: Toxicity, mechanisms and animal health risks. Anim Feed Sci Technol. 137(3-4): 283-298.

Petchkongkaew A, Taillandier P, Gasaluck P, Lebrihi A. 2008. Isolation of Bacillus spp. from Thai fermented soybean (Thua-nao): screening for aflatoxin B-1 and ochratoxin A detoxification. J Appl Microbiol. 104(5): 1495-1502.

Péteri Z, Téren J, Vágvölgyi C, Varga J. 2007. Ochratoxin degradation and adsorption caused by astaxanthin-producing yeasts. J. Food Microbiol. 24(3): 205-210.

Phillips TD, Kubena LF, Harvey RB, Taylor DR, Heidelbaugh ND. 1988. Hydrated sodium calcium aluminosilicate: A high affinity sorbent for aflatoxin. Poult Sci. 67(2): 253-260.

Phillips TD, Sarr AB, Grant PG. 1995. Selective chemisorption and detoxification of aflatoxins by phyllosilicate clay. Nat Toxins. 3(4):204-213.

Phillips TD, Lemke SL, Grant PG. 2002. Characterization of clay-based enterosorbents for the prevention of aflatoxicosis. Adv Exp Med Biol. 504: 157-71.

Phillips TD, Afriyie-Gyawu E, Williams J, Huebner H, Ankrah NA, Ofori-Adjei D, Jolly P, Johnson N, Taylor J, Marroquin-Cardona A, Xu L, Tang L, Wang JS. 2008. Reducing human exposure to aflatoxin through the use of clay: a review. Food Addit Contam Part A Chem Anal Control Expo Risk Assess. 25(2): 134-45.

Pierides M, El-Nezami H, Peltonen K, Salminen S, Ahokas J. 2000. Ability of dairy strains of lactic acid bacteria to bind aflatoxin M1 in a food model. J Food Prot. 63(5): 645-650.

Pimpukdee K, Tengjaroenkul B, Chaveerach P, Mhosatanun B. 2004. The characterization of clays and cetylpyridinium-exchanged clays for their ability to adsorb zearalenone. Thai $\mathrm{J}$ Vet Med. 34:23-31.

Plasencia J, Mirocha CJ. 1991. Isolation and Characterization of Zearalenone Sulfate Produced by Fusarium Spp. Appl Environ Microbiol. 57(1): 146-150.

Prandini A, Sigolo S, Filippi L, Battilani P, Piva G. 2009. Review of predictive models for Fusarium head blight and related mycotoxin contamination in wheat. Food Chem Toxicol. 47(5): 927-931.

Raju M, Devegowda G. 2000. Influence of esterified-glucomannan on performance and organ morphology, serum biochemistry and haematology in broilers exposed to individual and combined mycotoxicosis (aflatoxin, ochratoxin and T-2 toxin). British Poult Sci. 41(5): 640-650. 
Ramos AJ, Hernandez E, Pla-Delfina JM, Merino M. 1996. Intestinal absorption of zearalenone and in vitro study of non-nutritive sorbent materials. Int J Pharm. 128(1-2): 129137.

Raymond SL, Smith TK, Cotter PF, Boermans HJ, Sefton AE. 2003. Effects of feeding a blend of grains naturally contaminated with Fusarium mycotoxins on feed intake, serum chemistry, and hematology of horses, and the efficacy of a polymeric glucomannan mycotoxin adsorbent. J Anim Sci. 81(9): 2123-2130.

Richard JL. 2007. Some major mycotoxins and their mycotoxicoses-an overview. Int J Food Microbiol. 119: 3-10.

Rotter RG, Frohlich AA, Marquardt RR. 1989. Influence of dietary charcoal on ochratoxin A toxicity in Leghorn chicks. Can J Vet Res. 53(4): 449-453.

Ruhland M, Engelhardt G, Wallnöfer PL. 1996. Transformation of the mycotoxin ochratoxin A in plants .2. Time course and rates of degradation and metabolite production in cellsuspension cultures of different crop plants. Mycopathologia. 134(2): 97-102.

Rustom IYS. 1997. Aflatoxin in food and feed: occurrence, legislation and inactivation by physical methods. Food Chem. 59(1): 57-67.

Ryu D, Hanna MA, Eskridge KM, Bullerman LB. 2003. Heat stability of zearalenone in an aqueous buffered model system. J Agric Food Chem. 51: 1746-8.

Sabater-Vilar M, Malekinejad H, Selman MHJ, van der Doelen MAM, Fink-Gremmels J. 2007. In vitro assessment of adsorbents aiming to prevent deoxynivalenol and zearalenone mycotoxicoses. Mycopathologia. 163(2): 81-90.

Sarr AB, Clement BA, Phillips TD. 1990. Effects of molecular structure on the chemisorption of aflatoxin B1 and related compounds by hydrated sodium calcium aluminosilicate. The Toxicologist. 10(1):163.

Schaafsma AW, Hooker DC. 2007. Climatic models to predict occurrence of Fusarium toxins in wheat and maize. Int J Food Microbiol. 119(1-2): 116-125.

Schatzmayr G, Heidler D, Fuchs E, Mohln M, Taübel M, Loibner A-P, Braun R, Binder E-M. 2003. Investigation of different yeast strains for the detoxification of ochratoxin A. Mycotox Res. 19(2): 124-128.

Schatzmayr G, Zehner F, Taübel M, Schatmayr D, Klimitsch A, Loibner AP, Binder EM. 2006. Microbiologicals for deactivating mycotoxins. Mol Nutr Food Res. 50(6): 543-551.

Schisler DA, Khan NI, Boehm MJ, Slininger PJ. 2002. Greenhouse and Field Evaluation of Biological Control of Fusarium Head Blight on Durum Wheat. Plant Dis. 86(12): 1350-1356.

Schneweis I, Meyer K, Engelhardt G, Bauer J. 2002. Occurrence of zearalenone-4-beta-Dglucopyranoside in wheat. J Agric Food Chem. 50(6): 1736-1738.

Schneweis I, Meyer K, Ritzmann M, Hoffmann P, Dempfle L, Bauer J. 2005. Influence of organically or conventionally produced wheat on health, performance and mycotoxin residues in tissues and bile of growing pigs. Arch Anim Nutr. 59(3): 155-163. 
Schrödter R. 2004. Influence of harvest and storage conditions on trichothecenes levels in various cereals. Toxicol Letters. 153(1): 47-49.

Scott PM. 1998. Industrial and farm detoxification processes for mycotoxins. Rev Med Vet. 149: 543-548.

Shantha T. 1999. Fungal degradation of aflatoxin B1. Nat Toxins. 7(5): 175-178.

Shetty PH, Jespersen L. 2006. Saccharomyces cerevisiae and lactic acid bacteria as potential mycotoxin decontaminating agents. Trends Food Sci Technol. 17(2): 48-55.

Shima J, Takase S, Takahashi Y, Iwai Y, Fujimoto H, Yamazaki M, Ochi K. 1997. Novel detoxification of the trichothecene mycotoxin deoxynivalenol by a soil bacterium isolated by enrichment culture. Appl Environ Microbiol. 63(10): 3825-3830.

Sinha AK, Sinha KK. 1990. Insect pests, Aspergillus flavus and aflatoxin contamination in stored wheat: a survey at north Bihar (India). J Stored Prod Res. 26: 223-226.

Sisman T. 2006. The protective effect of hydrated sodium calcium aluminosilicate against the adverse effects of Aflatoxin B-1 on D. melanogaster. Toxicol Indus Health. 22(4): 173-179.

Skrinjar M, Rasic JL, Stojicic V. 1996. Lowering of ochratoxin A level in milk by yoghurt bacteria and bifidobacteria. Folia Microbiol. 41(1): 26-28.

Smiley RD, Draughon FA. 2000. Preliminary evidence that degradation of aflatoxin B1 by Flavobacterium aurantiacum is enzymatic. J Food Prot. 63(3): 415-418.

Smith EE, Phillips TD, Ellis JA, Harvey RB, Kubena LF, Thompson J, Newton G. 1994. Hydrated sodium calcium aluminosilicate reduction of AFM1 residues in dairy goat milk. $J$ Anim Sci. 72:677-682.

Solfrizzo M, Visconti A, Avantaggiato G, Torres A, Chulze S. 2001. In vitro and in vivo studies to assess the effectiveness of cholestyramine as a binding agent for fumonisins. Mycopathologia. 151(3): 147-153.

Soriano JM, Gonzalez L, Catala Al. 2005. Mechanism of action of sphingolipids and their metabolites in the toxicity of fumonisin B1. Prog Lipid Res. 44: 345-356.

Spotti M, Fracchiolla ML, Arioli F, Caloni F, Pompa G. 2005. Aflatoxin B1 binding to sorbents in bovine ruminal fluid. Vet Res Commun. 29(6): 507-515.

Stander MA, Bornscheuer UT, Henke E, Steyn PS. 2000. Screening of commercial hydrolases for the degradation of ochratoxin A. J Agric Food Chem. 48(11): 5736-5739.

Stanley VG, Ojo R, Woldesenbet S, Hutchinson DH, Kubena LF. 1993. The use of Saccharomyces cerevisiae to suppress the effects of aflatoxicosis in broiler chicks. Poult Sci. 72(10):1867-1872.

Stepanik T, Kost D, Nowicki T, Gaba D. 2007. Effects of electron beam irradiation on deoxynivalenol levels in distillers dried grain and solubles and in production intermediates. Food Addit Contam. 24(9):1001-1006.

Sundstøl Eriksen G, Pettersson H, Lundh T. 2004. Comparative cytotoxicity of deoxynivalenol, nivalenol, their acetylated derivatives and de-epoxy metabolites. Food Chem Toxicol. 42(4):619-24. 
Swamy H, Smith TK, Cotter PK, Boermans HJ, Sefton AE. 2002a. Effects of feeding a blend of grains naturally contaminated with Fusarium mycotoxins on swine performance, brain regional neurochemistry, and serum chemistry and the efficacy of a polymeric glucomannan mycotoxin adsorbent. J Anim Sci. 80(12): 3257-3267.

Swamy H, Smith TK, Boermans HJ, Sefton AE, Downey R, Woodward B. 2002b. Effects of feeding blends of grains naturally contaminated with Fusarium mycotoxins on production and metabolism in broilers. Poult Sci. 81(7): 966-975.

Swanson SP, Helaszek C, Buck WB, Rood HD, Haschek WM. 1988. The role of intestinal microflora in the metabolism of trichothecene mycotoxins. Food Chem Toxicol. 26(10): 823829.

Takahashi-Ando N, Kimura M, Kakeya H, Osada H, Yamaguchi I. 2002. A novel lactonohydrolase responsible for the detoxification of zearalenone: enzyme purification and gene cloning. Biochem J. 365(1): 1-6.

Takahashi-Ando N, Ohsato S, Shibata T, Hamamoto H, Yamaguchi I, Kimura M. 2004. Metabolism of zearalenone by genetically modified organisms expressing the detoxification gene from Clonostachys rosea. Appl Environ Microbiol. 70(6): 3239-3245.

Takahashi-Ando N, Tokai T, Hamamoto H, Yamagichi I, Kimura M. 2005. Efficient decontamination of zearalenone, the mycotoxin of cereal pathogen, by transgenic yeasts through the expression of a synthetic lactonohydrolase gene. Appl Microbiol Biotechnol. 67(6): 838-844.

Tangni EK, Simonis J, Larondelle Y, De Meeûs D'argenteuil L. 2006. Biological method for detoxification of a liquid food medium. US patent 2006/0263410 A1, Clark \& Brody, Washington.

Teniola AD, Addo PA, Brost IM, Färber $\mathrm{P}$, Janyhttp://www.sciencedirect.com/science? ob=ArticleURL\&_udi=B6T7K-4GSJPX5-

$1 \& \_u s e r=10 \& \_c o v e r D a t e=11 \% 2 F 25 \% 2 F 2005 \& \_r d o c=1 \& \_$fmt=high \&_orig=search\&_origin=search\&_sort=d\& _docanchor=\&view=c\&_searchStrId=1587022348\&_rerunOrigin=google\&_acct=C000050221\&_version=1\&_u rlVersion=0\&_userid=10\&md5=916090c0fe20d21dcc650ea138e5ac79\&searchtype $=\mathrm{a}-$ aff4 KD, Alberts JF, van Zylhttp://www.sciencedirect.com/science?_ob=ArticleURL\&_udi=B6T7K-4GSJPX5$1 \& \_$user $=10 \& \_$coverDate $=11 \% 2 \mathrm{~F} 25 \% 2 \mathrm{~F} 2005 \&$ rdoc $=1 \&$ fmt=high\& orig=search\& origin $=$ search\&_sort=d\& docanchor $=\&$ view $=c \& \_$searchStrId $=1587022348 \& \_$rerunOrigin $=$google \& $\_$acct $=C 000050221 \& \_v e r s i o n=1 \& \_u$

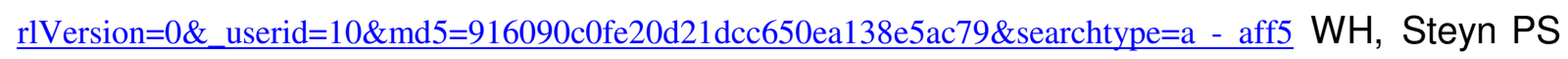
Holzapfel WH. 2005. Degradation of aflatoxin B-1 by cell-free extracts of Rhodococcus erythropolis and Mycobacterium fluoranthenivorans sp nov DSM44556(T). Int J Food Microbiol. 105(2): 111-117.

Tomasevic-Canovic M, Dakovic A, Rottinghaus G, Matijasevic S, Duricic M. 2003. Surfactant modified zeolite-new efficient adsorbents for mycotoxins. Micro Meso Materials. 61(13):173-180. 
Ueno Y, Nakayama K, Ishii K, Tashiro F, Minoda Y, Omori T, Komagata K. 1983. Metabolism of T-2 toxin in Curtobacterium sp. strain 114-2. Appl Environ Microbiol. 46(1): 120-127.

Utermark J, Karlovsky P. 2007. Role of zearalenone lactonase in protection of Gliocladium roseum from fungitoxic effects of the mycotoxin zearalenone. Appl Environ Microbiol. 73(2): 637-642.

Varga J, Rigo K, Teren J. 2000. Degradation of ochratoxin A by Aspergillus species. Int J Food Microbiol. 59: 1-7.

Vekiru E, Hametner C, Mitterbauer R, Rechthaler J, Adam G, Schatzmayr G, Krska R, Schuhmacher R. 2010. Cleavage of Zearalenone by Trichosporon mycotoxinivorans to a Novel Nonestrogenic Metabolite. Appl Environ Microbiol. 76(7): 2353-2359.

Visconti A, Haidukowski EM, Pascale M, Silvestri M. 2004. Reduction of deoxynivalenol during durum wheat processing and spaghetti cooking. Toxicol Letters. 153(1): 181-189.

Völkl A, Vogler B, Schollenberger M, Karlovsky P. 2004. Microbial detoxification of mycotoxin deoxynivalenol. J Basic Microbiol. 44(2): 147-156.

Voss KA, Smith GW, Haschek WM. 2007. Fumonisins: Toxicokinetics, mechanism of action and toxicity. Anim Feed Sci Technol. 137(3-4): 299-325.

Voss KA, Bullerman LB, Bianchini A, Hanna MA, Ryu D. 2008. Reduced toxicity of fumonisin B1 in corn grits by single-screw extrusion. J Food Prot. 71(10): 2036-2041.

Watts CM, Chen YC, Ledoux DR, Broomhead JN, Bermudez AJ, Rottinghaus GE. 2003. Effects of multiple mycotoxins and a hydrated sodium calcium aluminosilicate in poultry. Inter J Poult Sci. 2:372-378.

Wegst W, Lingens F. 1983. Bacterial degradation of ochratoxin A. FEMS Microbiol Lett. 17: 341-344.

WHO Food Additives Series 47. 2001. Safety evaluation of certain mycotoxins in food. Deoxynivalenol. Geneva. WHO. 419-528.

Wu F. 2007. Measuring the economic impacts of Fusarium toxins in animal feeds. Anim Feed Sci Technol. 137(3-4): 363-374.

Xiao H, Madhyastha S, Marquardt RR, Li S, Vodela JK, Frohlich AA, Kemppainen BW. 1996. Toxicity of ochratoxin A, its opened lactone form and several of its analogs: structure-activity relationships. Toxicol Appl Pharmacol. 137(2):182-192.

Yiannikouris A, Andre G, Buléon A, Jeminet G, Canet I, François J, Bertin G, Jouany JP. 2004. Comprehensive conformational study of key interactions involved in zearalenone complexation with beta-D-glucans. Biomacromolecules. 5(6): 2176-2185.

Yiannikouris A. 2004. Etude des mécanismes chimiques impliqués dans la complexation de mycotoxines par les composants de la paroi cellulaire de la levure Saccharomyces cerevisiae. Thèse doctorale de l'Université Blaise Pascal, Clermont Ferrand.

Yoshizawa T, Hiroaki T, Ohi T. 1983. Structure of a novel metabolite from deoxynivalenol, a trichothecene mycotoxin, in animals. Agric Biological Chem. 47: 2133-2135. 
Young JC, Zhou T, Yu H, Zhu H, Gong J. 2007. Degradation of trichothecene mycotoxins by chicken intestinal microbes. Food Chem Toxicol. 45(1): 136-143.

Zhou T, He J, Gong J. 2008. Microbial transformation of trichothecene mycotoxins. World Mycotoxin Journal. 1(1): 23-30. 


\section{Tables}

Table 1: Chemical structure of zearalenone metabolites

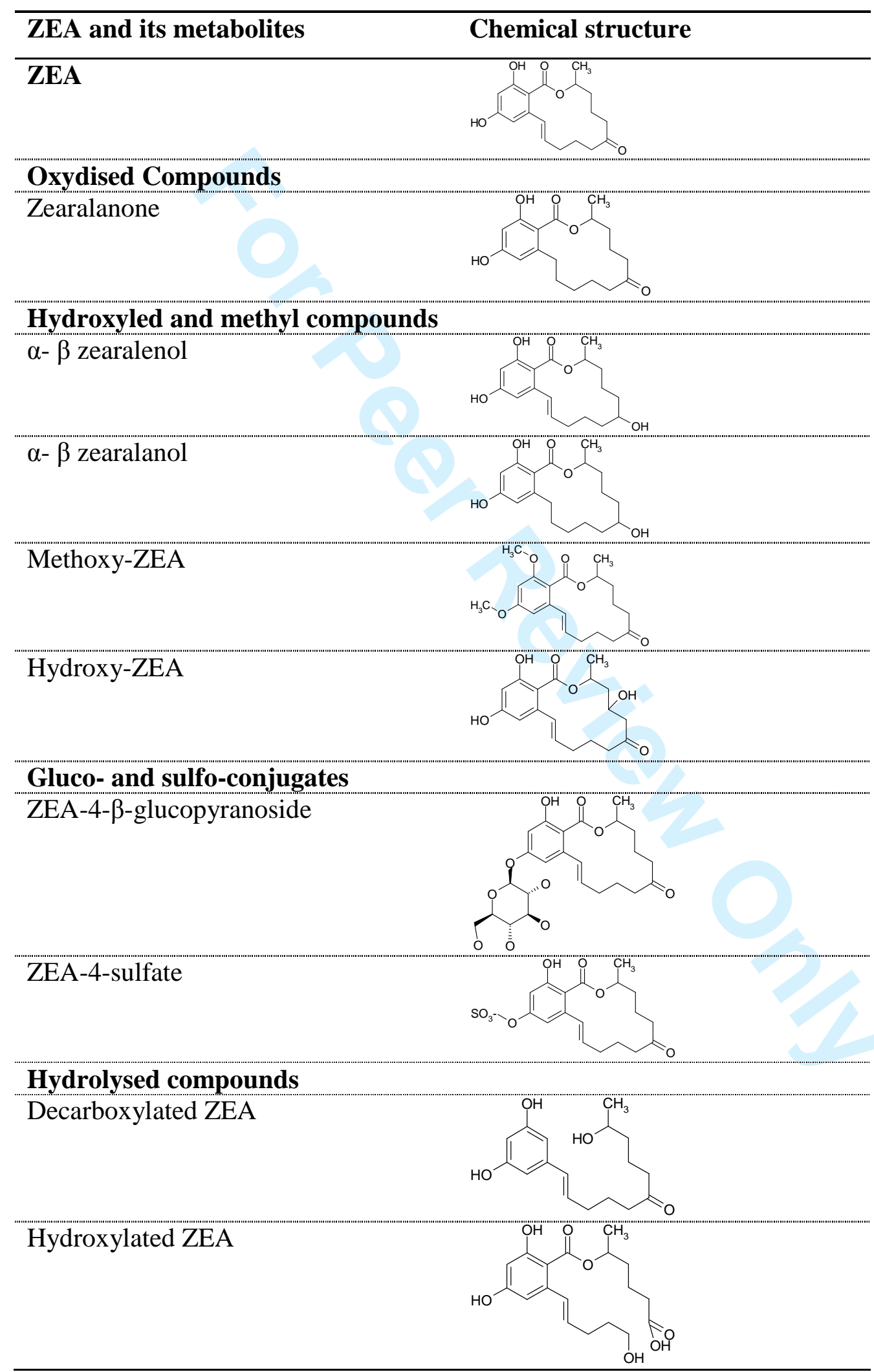


Table 2: Chemical structure of deoxynivalenol metabolites

DON and its metabolites


Table 3: Chemical structure of metabolites of T-2 toxin and HT-2 toxin

T-2 or HT-2 toxin and their
metabolites
T-2 toxin
De-acetylate molecules
$\mathrm{T}-2$ triol


Table 4: Chemical structure of fumonisin B1 metabolites

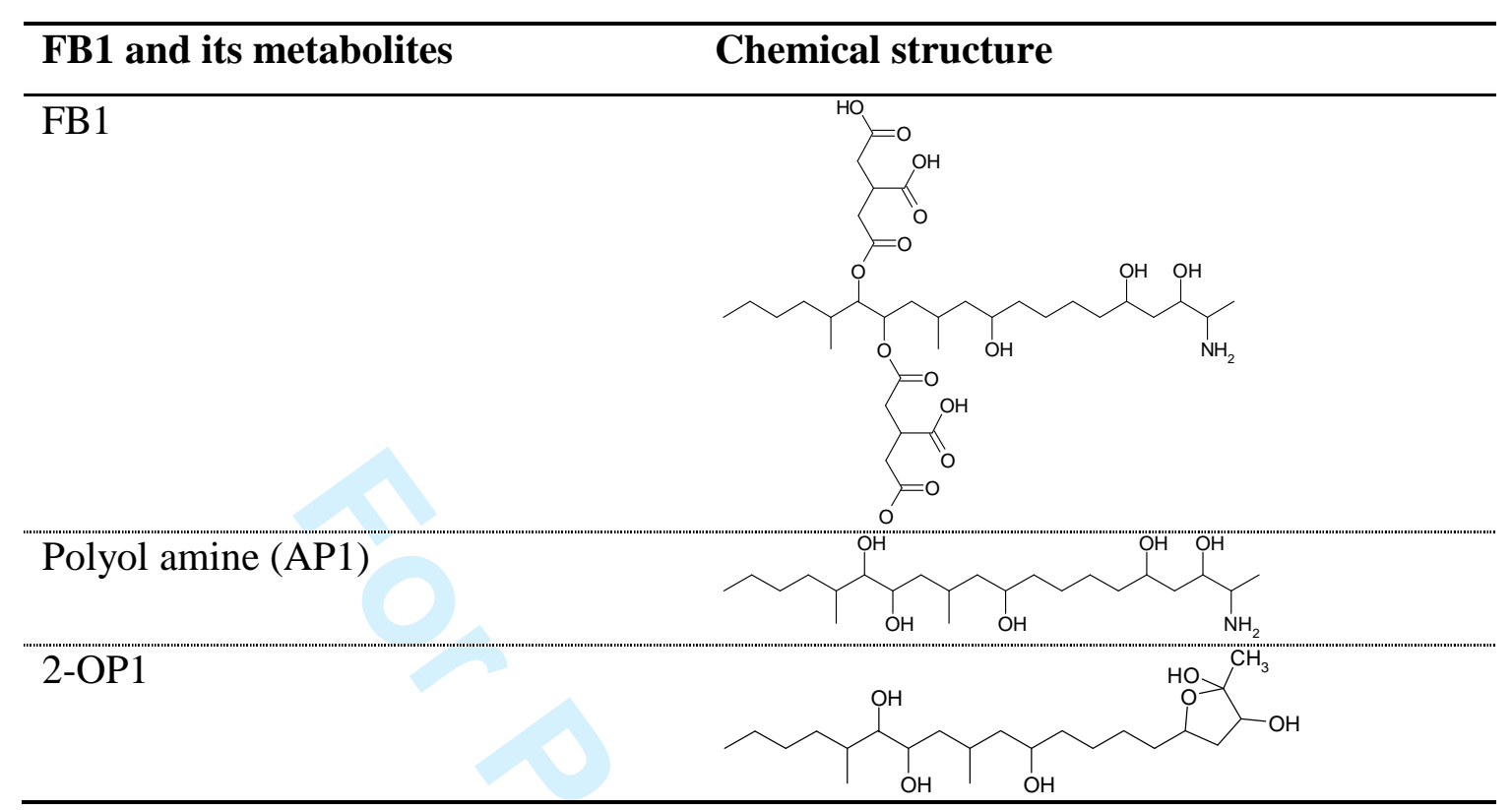


1

2

3

4

5

6

7

8

9

10

11

12

13

14

15

16

17

18

19

20

21

22

23

24

25

26

27

28

29

30

31

32

33

34

35

36

37

38

39

40

41

42

43

44

45

46

47

48

49

50

51

52

53

54

55

56

57

58

59

60

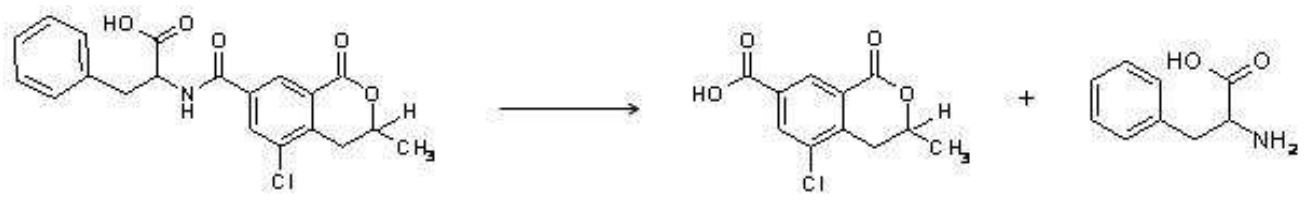

Figure 1: Transformation of OTA to Ota and phenylalanine $159 \times 24 \mathrm{~mm}(96 \times 96 \mathrm{DPI})$ 